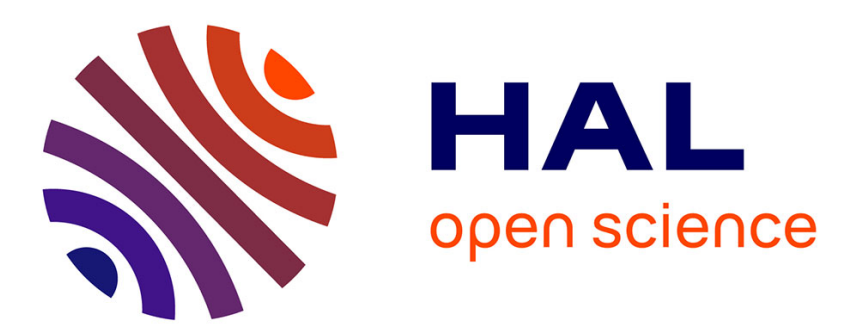

\title{
Monetary Policy, Credit Risk, and Profitability: The Influence of Relationship Lending on Cooperative Banks' Performance \\ Bruno de Menna
}

\section{To cite this version:}

Bruno de Menna. Monetary Policy, Credit Risk, and Profitability: The Influence of Relationship Lending on Cooperative Banks' Performance. 2021. hal-03138738

\section{HAL Id: hal-03138738 \\ https://hal.science/hal-03138738}

Preprint submitted on 11 Feb 2021

HAL is a multi-disciplinary open access archive for the deposit and dissemination of scientific research documents, whether they are published or not. The documents may come from teaching and research institutions in France or abroad, or from public or private research centers.
L'archive ouverte pluridisciplinaire HAL, est destinée au dépôt et à la diffusion de documents scientifiques de niveau recherche, publiés ou non, émanant des établissements d'enseignement et de recherche français ou étrangers, des laboratoires publics ou privés. 


\title{
Monetary policy, credit risk, and profitability: The influence of relationship lending on cooperative banks' performance
}

\author{
Bruno De Menna* \\ Université de Toulouse, Institut d'Études Politiques, Department of Economics (LEREPS) \\ Manufacture des Tabacs, 21 allée de Brienne, 31042 Toulouse Cedex \\ February 11, 2021
}

\begin{abstract}
Financial theory indicates that low interest rates hamper credit risk and profitability, two interrelated components of banks' balance sheets. Using a simultaneous equations framework, we investigate the effects of euro area monetary easing on cooperative banks' performance depending on their commitment to relationship lending. First, we find no evidence of a risk-taking channel of monetary policy for consolidated cooperative banks. Further, the profitability of relationship-based cooperative banks is more severely hit in a low interest rate environment than that of consolidated cooperative banks. This raises issues about the middle-term durability of relationship lending when rates hold "low-for-long." Finally, non-cooperative banks and relationship-based cooperative banks both increase credit risk under accommodating monetary policy. However, we suggest that these similarities do not occur for the same reasons: while non-cooperative banks prioritize profitability through higher credit risk when interest rates fall, relationship-based cooperative banks instead increase their capital buffers to ensure credit access to their customers, which mainly comprise small businesses and high-risk firms.
\end{abstract}

Keywords: Monetary policy, credit risk, profitability, cooperative banks, relationship lending.

JEL classification: E52, G21, P13.

*Corresponding author (e-mail address: bruno.de-menna@ut-capitole.fr).

\section{Introduction}

Following 10 years of accommodating monetary policy, the European Central Bank (ECB) has provided forward guidance in response to the COVID-19 pandemic on the future path of key interest rates, saying that it expects them to remain at their present or even lower levels ${ }^{1}$. Therefore, it seems that the term "low-for-long" is now more relevant than ever when it comes to future trends in interest rates in the European banking industry. While promoting economic recovery and enhancing banks' balance sheets, persistent low interest rates might also significantly erode bank credit risk - through the risk-taking channel of monetary policy transmission (Borio and Zhu, 2012) - as well as profitability through low market valuations and price-to-book ratios well below one (Claessens et al., 2018).

Owing to their strong commitment to traditional financial intermediation, cooperative banks might be more vulnerable in terms of credit risk and profitability under low rates, as they are more dependent on interest income than their non-cooperative counterparts. Accordingly, these credit institutions are com-

\begin{tabular}{lcccccc}
\hline${ }^{1}$ See & the & ECB & press & release & on & mone- \\
tary & policy & decisions & on & April & 30, & 2020 , \\
ecb.europa.eu/press $/ \mathrm{pr} /$ date/2020/html/ecb.mp200430 & 1 leaa128265.en.
\end{tabular}

pelled to balance their historical cooperative ethos (Ayadi et al., 2010) and their ability to survive in the banking industry, which decreasing interest rates make all the more competitive. Most cooperative groups have addressed this issue through structural consolidation, which aims to reduce the operational costs associated with decentralized (and, sometimes, unprofitable) networks of local and regional branches. Ultimately, however, this reduces geographical coverage, which seriously hampers customer proximity, a key element in relationship lending (Elsas, 2005) and the identity of cooperative banks. Table A1 confirms this trend for European cooperative banks: between 2010 and 2019, the overwhelming majority of cooperative brands in the European banking sector experienced a sharp rise in the number of customers per branch, an indicator used to proxy for the territorial coverage of cooperative banks ${ }^{2}$ (EACB, 2020a), with -in the most extreme cases-increases rising to $174 \%$ and $208 \%$ for the cooperative groups Österreichischer Volksbanken in Austria and Rabobank in the Netherlands, respectively.

These figures raise fundamental questions about the ability of cooperative banks to either stand apart from the competition through relationship lending or move further away from their

\footnotetext{
${ }^{2}$ The higher the index, the lower is the territorial coverage of cooperative banks.
} 
raison d'être as interest rates remain low. Specifically, can cooperative banks opting for consolidation in such a low interest rate environment preserve their specificities or behave similarly to their non-cooperative counterparts in terms of credit risk and profitability? What changes in credit risk and profitability have cooperative banks, despite their increasingly small interest margins, chosen to preserve their relationship lending model? To date, answers to these questions are largely elusive in the literature.

To extend these lines of research and determine the impact of relationship lending on credit risk and profitability in a low interest rate environment, we investigate the unconsolidated statements of cooperative and non-cooperative banks from 10 euro area countries between 2010 and 2019, a period characterized by historical monetary easing by the ECB. We also rely on the territorial coverage proxy proposed by the European Association of Co-operative Banks (EACB, 2020a) to classify cooperative banks in our sample as consolidated (i.e., above the median value of the number of customers per branch in 2019) or relationship-based (i.e., below the median value). Moreover, to be consistent with the empirical findings that bank credit risk and profitability might be jointly determined (Athanasoglou et al., 2008), we estimate a simultaneous equations model. Our final dataset consists of 3998 banks, including 1862 noncooperative banks ( $46.6 \%$ of the full sample) and 2136 cooperative banks (among which 151 are consolidated and 1985 are relationship-based).

Based on this empirical framework, we extend the literature in several directions. First, we find no evidence of the presence of a risk-taking channel of monetary policy for consolidated cooperative banks, whereas such a channel is extensively found in the euro area for non-cooperative banks. Consolidated cooperative banks therefore tend to stand out from their non-cooperative counterparts in terms of monetary policy transmission to their credit risk. Second, we highlight that the profitability of cooperative banks preserving their relationship lending model is more severely hit by a low interest rate environment than that of cooperative banks opting for consolidation. This raises issues about the middle-term durability of relationship lending in a low interest rate environment. Third, we find that noncooperative banks and relationship-based cooperative banks are both concerned by the risk-taking channel of monetary policy transmission, which increases their credit risk under accommodating monetary policy conditions. Nevertheless, we suggest that such similarities do not occur for the same reasons, as relationship lending is associated with a fundamentally different lending process than transactions-based lending technologies that devote significantly lower proportions of their assets to lending to small businesses (Berger and Udell, 2002). Accordingly, the greater the relationship lending strategy of a cooperative bank, the greater is its willingness to undertake credit risk, which is particularly valuable to high-risk firms and small businesses, as they are often informationally opaque and have far fewer external finance alternatives than large companies.

In Section 2, we provide the motivation for the study and review the literature on relationship lending as well as the effects of expansionary monetary policy on bank credit risk and profitability. Section 3 discusses the empirical methodology, while Section 4 outlines the data used in the sample. Section 5 describes our findings and Section 6 concludes.

\section{Motivation for the study and related litera- ture}

\subsection{Motivation for the study}

Cooperative banking emerged in the United States during the 19 th century as a solution to imperfect markets, especially those featuring information asymmetries between bank associates and borrowers (Hansmann, 1996). In Europe, it appeared in the second half of the 19th century at the instigation of FrédéricGuillaume Raiffeisen who helped disseminate credit unions in Austria, France, Germany, Italy, and Spain. Nowadays, cooperative banks have gained prominence across the European Union (EU). In 2019, the European Association of Co-operative Banks recorded more than 213 million customers, 85 million members (which represents one in every five European citizens), 42,521 branches, 4154 billion Euro in deposits, and 7932 billion Euro in total assets (EACB, 2020b).

As stated by Ayadi et al. (2010), a key characteristic of cooperative banks is their cooperative ethos linked to a strong focus on retail banking: cooperative banks know their customers relatively well, including their risk profiles (Lang et al., 2016), and can collate a great deal of soft information (which is hard to collect) on their creditworthiness (Berger et al., 2005). Their strong local presence and customer proximity also reduce information asymmetries in lender-borrower relationships (Fiordelisi and Mare, 2014).

Branch expansion also benefits local economic growth and offers tailored services to local people (Bernini and Brighi, 2018). Cooperative banks might even be geographically concentrated in some EU countries (e.g., Italy and Germany) and engage in local monopolistic competition to capture a strong comparative advantage in developing close customer relationships (Catturani and Stefani, 2016). Consequently, they end up being key financing partners of small and medium-sized enterprises as well as retail customers looking for a bank receptive to their needs.

Nevertheless, a low interest rate environment (Altavilla et al., 2018) also provides fertile ground for the risk-taking channel of monetary policy (Borio and Zhu, 2012). In times of monetary easing such as those in the euro area since the global financial crisis, credit institutions are highly likely to undertake credit risk in response to squeezed profits from traditional interestgenerating activities. Facing low rates and the associated higher 
competition in the banking industry, cooperative banks have strived to make their model a strength. For instance, their business model comprises simpler structures less impacted by the global financial crisis than those of non-cooperative banks (McKillop et al., 2020), even in countries severely hit economically and socially (Lang et al., 2016). Moreover, their stakeholder organization (based on the principle of "one person = one vote") allows members to be directly involved in the cooperative's management to exert checks and balances at each business level. Greater transparency and the improved identification of customers' creditworthiness might ultimately minimize credit risk, even when monetary policy is eased for a prolonged period. This provides us with the first hypothesis tested in this study.

Hypothesis 1. Thanks to the specificities of their business model, cooperative banks are less exposed to the risk-taking channel of monetary policy than non-cooperative banks.

Relationship lending-on which cooperative banks have historically relied-also has potential weaknesses. Among them lies a stronger dependence on domestic interest income, which becomes a major challenge in a low interest rate environment ${ }^{3}$. In the short run, the negative impact on profitability can be mitigated by cost cutting and focusing on non-interest income. However, in the longer term, capitalization issues might encourage consolidation as financial institutions merge in the pursuit of economies of scale (Altavilla et al., 2018; Bexley, 2016). As banking institutions grow larger and more organizationally complex through consolidation, Berger and Udell (2002) note that they are ultimately less likely to choose to make relationship loans.

Accordingly, the cooperative banking sector has responded to lax monetary policy reducing their territorial coverage since the global financial crisis, mainly because maintaining extensive networks of local branches implies significant organizational costs (Bernini and Brighi, 2018) ${ }^{4}$. Yet, branch closure seriously hampers the relationship lending model and dwindles the comparative advantage cooperative banks have so far used to stand out in the banking industry (Jovanovic et al., 2017) ${ }^{5}$. Therefore, "low-for-long" interest rates (Claessens et al., 2018) might jeopardize the local-based model of cooperative banks and shed light on their dilemma of how to reduce costs while preserving their regional entrenchment.

Assuming that bank performance is impaired by low inter-

\footnotetext{
${ }^{3}$ Another problem identified by Meyer (2018) is that cooperative banks have increasingly less room to implement differentiated interest rates (i.e., below market rates (Agarwal and Hauswald, 2010)) than the rest of the banking industry owing to their better knowledge of customers' creditworthiness (Meyer, 2018; Ayadi et al., 2016).

${ }^{4}$ See Table A1 on the upward trend of the number of clients per branch - a proxy for customer proximity - of European cooperative banks between 2010 and 2019 .

${ }^{5}$ Jovanovic et al. (2017) also points out that branch closure leads to the greater use of online banking, which hinders cooperative banks' key values regarding customer proximity.
}

est rates (Bikker and Vervliet, 2018), the second hypothesis of this study differentiates cooperative banks opting for consolidation (to reduce their organizational costs and, ultimately, the impact of monetary easing on their profitability) and cooperative banks preserving their relationship lending model through (costly) decentralized territorial coverage.

Hypothesis 2. The profitability of cooperative banks preserving their relationship lending model is more severely hit by a low interest rate environment than that of cooperative banks opting for consolidation.

Examining the role of the bank-customer relationship in credit risk, Jiménez and Saurina (2004) highlight that a close relationship increases the willingness of the bank to take more risk. This occurs primarily because individuals and non-financial companies can benefit from a close relationship with their bank through easier access to credit (i.e., the amount of credit they obtain, how much it costs them, the protection they have during recessions, and even the implicit insurance of the cost of finance) (Petersen and Rajan, 1994). A direct result of such a close bank-customer relationship is the production of informational rents for the bank involved (Rajan, 1992), enabling it to exercise a degree of market power (at least in the future). Banks might ultimately be prepared to finance riskier borrowers or projects: the more they develop relationship lending, the greater is their credit risk willingness.

By contrast, when a firm or an individual has a relationship with several banks, none of them can monopolize their information on the borrower's quality and thus cannot extract rents, which considerably diminishes the incentive to finance higher-risk borrowers (Jiménez and Saurina, 2004). Nevertheless, Boot (2000) stresses that relationship lending might also help alleviate adverse selection and moral hazard problems.

Peltoniemi (2007), furthermore, investigates data on small businesses' loans from a major Finnish bank, finding that a longterm bank-firm relationship is beneficial, especially for high-risk firms that are, interestingly, more likely to provide personal guarantees. As the relationship matures, the loan premiums for risky firms decrease at a higher rate than those for safe firms, meaning that high-risk firms tend to preserve a long-term relationship with their bank to derive economic benefits. Ultimately, lasting bank-firm relationships are particularly valuable and desirable to small businesses.

In line with these theoretical predictions, we test whether, in a low interest rate environment, cooperative banks committed to relationship lending are willing to assume increased credit risk $^{6}$. In times of low interest rates such as the 2010-2019 period considered in the present analysis, we therefore expect

\footnotetext{
${ }^{6}$ For illustrative purposes, Table 3 shows that, on average, the loan loss provision of relationship-based cooperative banks is higher than that of consolidated cooperative banks (this difference being not significant, though).
} 
to observe a negative relationship between the monetary policy stance and credit risk of relationship-based cooperative banks.

As shown in Table 1 and Table A2, we approximate the strength of the relationship between a cooperative bank and its customers through the territorial coverage of its local branches. Based on the most recent data provided by the European Association of Co-operative Banks (EACB, 2020a), a cooperative bank is considered to be consolidated (i.e., with lower territorial coverage and, therefore, little commitment to relationship lending) when the number of clients per branch is above its 2019 median value. Conversely, a cooperative bank is categorized as relationship-based (i.e., with higher territorial coverage and, therefore, strong commitment to relationship lending) when the number of clients per branch is below its 2019 median value. This methodological choice is driven by Berger and Udell (2002), who consider that such banks are more often headquartered closer to potential relationship customers, thereby reducing the problems associated with transmitting soft information about the local firm, owner, and community to senior management. Accordingly, this leads us to the third hypothesis empirically assessed in this study.

Hypothesis 3. Cooperative banks preserving their relationship lending model in a low interest rate environment are prone to assume greater credit risk than cooperative banks opting for consolidation.

\subsection{Related literature}

Our empirical analysis draws on three strands of the literature dedicated to the impact of monetary policy on credit institutions: the risk-taking channel of monetary policy transmission (Section 2.2.1), the impact of interest rates on bank profitability (Section 2.2.2), and the response of cooperative banking and relationship lending to monetary policy stances (Section 2.2.3). We discuss these three strands below.

\subsubsection{The risk-taking channel of monetary policy transmission}

In the aftermath of the global financial crisis, a growing debate ensued on whether risk-taking incentives at financial institutions are shaped by the monetary conditions prevailing in the economy (Caselli et al., 2020). As such, monetary policy might affect bank risk through two mechanisms (Angeloni et al., 2015).

On the one hand, a first channel operates through changes in the composition of the asset side of banks' balance sheets (Delis et al., 2017) when a prolonged period of low interest rates induces banks to search for yields by making riskier assets more attractive than safe bonds. This leads to higher procyclical risk within the financial system (Rajan, 2006) and a growing number of weakened bank portfolios (Dell'Ariccia and Marquez, 2006)

The second channel, on the other hand, refers to the impact of monetary policy on banks' funding as they find it more profitable to adjust the combination of capital and short-term funding by increasing leverage (Valencia, 2014). However, theory predicts that the effects of interest rates on leverage depend on the extent to which banks can change their capital structures (Dell'Ariccia et al., 2014) and whether the yield curve is upward sloping.

As low interest rates boost asset and collateral values while reducing volatility, banks might also downsize their estimates of probabilities of default and assume higher risk positions (Delis et al., 2017). Analyzing the Spanish banking industry, Jiménez et al. (2014) find that lower overnight rates lead weakly capitalized banks to grant more credit and higher loan volumes with fewer collateral requirements to ex-ante risky borrowers than higher rates. Using a factor-augmented vector autoregressive model for the United States between 1997 and 2008, Buch et al. (2014) prove that small domestic banks significantly increase the supply of new loans to high-risk borrowers following an expansionary monetary policy shock.

Recently, Bikker and Vervliet (2018) indicate that a low interest rate environment might cause banks to reduce their level of credit loss provisioning and expand their trading activities to reduce their reliance on lending business. Exploring the existence of an international bank lending channel, Schmidt et al. (2018) also find that monetary policy tightening abroad reduces credit supply at home, particularly for US monetary policy changes.

Based on a sample of commercial, savings, and cooperative banks in the euro area between 2001 and 2008, Delis and Kouretas (2011) present strong empirical evidence that low interest rates increase bank risk-taking, although this effect is less pronounced for French institutions, which hold a relatively low level of risk assets on average. Further, the distributional effects of interest rates on bank risk-taking due to individual bank characteristics reveal that the impact of interest rates on risk assets is diminished for banks with higher equity capital and amplified for banks with higher off-balance sheet items. In the same vein, Bonfim and Soares (2018) demonstrate that the impact of monetary policy on risk-taking strategies is stronger among banks with weaker capital ratios and larger liquidity buffers than others.

When analyzing both conventional and unconventional monetary policy measures, Brana et al. (2019) find that loosening monetary policy may have harmful effects on bank risk-taking but that such a relation is non-linear: when interest rate indicators are below a certain threshold, the negative relationship between bank risk and monetary policy is stronger. In particular, accounting for central banks' balance sheet policy indicates that additional liquidity encourages banks to take riskier positions. Similarly, Vari (2020) shows that interbank market fragmentation might disrupt the transmission of monetary policy by leading short-term interest rates to depart from central bank policy rates. 


\subsubsection{The impact of interest rates on bank profitability}

Investigating how macroeconomic and bank variables affect banks' net interest income and profitability, Demirgüç-Kunt and Huizinga (1999) find that higher interest rates are associated with higher net interest margins and profits, especially in countries where interest rates on deposits are more likely to be controlled and below the market level. Based on a sample of European, American, and Japanese international banks, Borio et al. (2017) find a positive relationship between the level of short-term rates and slope of the yield curve, on the one hand, and bank profitability, on the other hand. This suggests that the positive impact of the interest rate structure on net interest income dominates the negative impact on loan loss provision and non-interest income. They point out that such an effect is stronger when interest rates are low and the slope is steep (i.e., when non-linearities are present), indicating that unusually low interest rates and an unusually flat term structure erode bank profitability over time.

Alternatively, Genay (2014) argue that interest rate changes have a greater short-run impact on small banks, as they depend more on the traditional intermediation of retail deposits and loans than larger banks, many of which are priced based on floating (prime) rates. While large US banks typically have a greater ability to manage interest rate risks and are less affected by low rates, Covas et al. (2015) find that their funding cost advantage and net interest margins have declined more than those of small banks since the global financial crisis. Moreover, Busch and Memmel (2015) analyze the German banking industry where the long-run effect of a 100 basis point change on net interest margins is small (at around 7 basis points) in "normal" interest rate environments.

Differences between small and large banks in terms of monetary policy impacts on profitability also arise from differences in the compositions of their assets and liabilities, in the competition for funds and lending opportunities, and in their business models (Claessens et al., 2018). Accordingly, Gomez et al. (2020) suggest that US banks' assets are more sensitive to interest rate risks than are their liabilities, while such sensitivity varies across banks and might lead lending to respond differently to monetary policy depending on how bank financing is affected. In this case, the variations in exposure to interest rate changes across banks are due to differences in competition in deposit and loan markets. Conversely, Drechsler et al. (2017) find that deposit interest rates tend to change less with monetary policy changes in markets where deposit competition is lower.

English et al. (2018) show that an increase in interest rates results in higher interest margins for about a year, after which bank profits turn significantly negative. Following increases in the level and slope of the yield curve, reductions in profits reflect a shift in the composition of banks' balance sheets. In particular, increases in rates lead to an outflow of core deposits, which are an inexpensive source of funding relative to market alternatives. Ultimately, changes in interest rates only have moderate and transitory effects on bank earnings.

\subsubsection{Response of cooperative banking and relationship lending to monetary policy stances}

Elsas (2005) defines relationship lending as a long-term implicit contract between a bank and its debtor, which leads the former, thanks to information production and repeated interaction with the borrower over time, to accumulate private information, thereby establishing close ties. Such ties create benefits for the lending institution such as intertemporal smoothing, increased credit availability, the enhancement of the borrower's project payoffs, and more efficient decisions if borrowers face financial distress. Therefore, relationship lending is one of the most important technologies employed by banks to extend credit to informationally opaque small businesses without strong financial ratios, collateral, or credit scores (Berger and Udell, 2002). It allows them to obtain bank financing by augmenting relatively weak hard information with soft information gained over time through contact with firms, their owners, and their local communities at a variety of levels.

As local institutions, cooperative banks acquire specialized knowledge by cultivating relationships between staff and customers. The resulting proximity facilitates access to soft information, defined by Berger and Udell (2002) as information difficult to quantify, verify, and transmit through the layers of management and ownership of a banking organization ${ }^{7}$, which is used to mitigate information asymmetry and more readily provide credit to informationally opaque borrowers. By contrast, large credit institutions have little commitment to relationship lending, as they would rather place weight on hard information (also called transactions-based technologies) and are more open to borrowers with lower informational opacity (McKillop et al., 2020). Indeed, Uchida et al. (2012) points out that even if large banks appear to have an equivalent potential to underwrite relationship loans, they choose instead to focus their resources on transactions lending.

Neuberger et al. (2008) suggest that localism and cooperative ownership are positively related to the relational orientation of financial institutions, as they avoid the organizational diseconomies and coordination problems often associated with large, multilayered institutions opting for standardized credit policies based on hard information (Berger and Udell, 2002). Moreover, Presbitero and Zazzaro (2011) find that where relationship lending techniques are already widely used by numerous cooperatives and savings banks, an increase in out-of-market competition drives them to further cultivate their relationship ties with customers. More recently, Donker et al. (2020) highlight that borrowing from relationship lenders lowers the loan spread by 17 basis points compared with borrowing from non-

\footnotetext{
${ }^{7}$ For instance, appraisals of real estate might require the expertise of individuals with specialized knowledge of local markets.
} 
relationship lenders, implying that relationship lenders can benefit borrowers. They also show that borrowers often choose to remain with their relationship bankers because of the more favorable loan terms and high costs of switching lenders.

Based on the contracts database of a French cooperative bank, Dereeper et al. (2020) show that a strong bank-firm relationship results in a lower spread for loan applications during the high phase of the business cycle, while, in a downturn, the stronger the bank-firm relationship, the higher is the interest rate. Importantly, this means that weaker interest rates appear only in normal or good periods, while the hold-up problem only arises during economic recessions. Focusing on the EU banking industry, Kuc and Teply (2019) find structural differences in the priorities and behavior of European cooperative and commercial banks in a low interest rate environment: commercial banks tend to focus on maintaining their profitability, whereas cooperative banks favor stability by increasing their capital buffers.

While Hasan et al. (2014) provide evidence that Polish cooperative banks lend more to small businesses than large domestic and foreign-owned banks, Ferri et al. (2014) conclude that stakeholder banks decrease their loan supply to a lesser extent than shareholder banks following a monetary policy contraction. In particular, cooperative banks continued to smooth the impact of tighter monetary policy on their lending during the global financial crisis, acknowledging that the presence of stakeholder banks in the economy has the potential to reduce credit supply volatility. In turn, Agarwal and Hauswald (2010) prove that interest rates might even decrease with the length and strength of the relationship between a cooperative bank and firm, as borrower proximity facilitates the collection of soft information. Finally, cooperative banks might decide to set loan interest rate and saving rate ceilings (Ferrari et al., 2018) to protect borrowers by offering access to credit at reasonable interest rates.

\section{Methodology}

We investigate the contribution of monetary policy to explaining banks' credit risk and profitability depending on whether they display a cooperative ownership structure and, if so, whether they manage their network of local branches on a centralized basis. Based on the most recent data provided by EACB (2020b) on the 2019 territorial coverage of European cooperative banks, we compute the median value of the number of clients per branch of the cooperative banks included in our sample (see Table $\mathrm{A} 1$ ). We then categorize a cooperative bank as relationshipbased $^{8}$ (Cornée, 2014; Bülbül et al., 2013; Stein, 2012) (consolidated) if the number of clients per branch is below (above) the 2019 median value described above.

\footnotetext{
${ }^{8}$ The relationship-based category includes cooperative banks with a relatively high territorial coverage of local branches (i.e., a strong commitment to relationship lending) as opposed to consolidation and integration (Ory and Lemzeri, 2012).
}

As previous studies suggest that credit risk and profitability might be linked by a bidirectional causal relationship (Athanasoglou et al., 2008), we consider a dynamic simultaneous equations system to deal with endogeneity issues. In the first equation, we regress the credit risk index on a set of explanatory variables identified in the literature to which we add profitability variables (using several proxies; see below) and the monetary policy stance. In the second equation, we regress the profitability variable on a set of independent variables also identified in the literature in addition to the credit risk proxy and an indicator of monetary policy. All bank-level data originate from Fitch Connect, while all country-level data stem from Eurostat (except for spreads, which are retrieved from Thompson Reuters Eikon; see Table 1). The empirical model to be estimated is specified by the following dynamic simultaneous equations system (the subscripts $b$ and $t$ denote bank and time, respectively):

$$
\left\{\begin{aligned}
L L P_{b, t}= & \alpha_{b, t}+\beta L L P_{b, t-1}+\gamma \Pi_{b, t}+\delta M P 1_{t} \\
& +\zeta E D C 1_{b, t-1}+\eta \operatorname{Real} G D P_{t}+\epsilon_{b, t} \\
\Pi_{b, t}=\theta_{b, t} & +\iota \Pi_{b, t-1}+\kappa L L P_{b, t}+\lambda M P 2_{t} \\
& +\mu E D C 2_{b, t-1}+\nu \operatorname{Real} G D P_{t}+\xi_{b, t}
\end{aligned}\right.
$$

Where:

- $L L P_{b, t}$ is the loan loss provision to total gross loans ratio of bank $b$ at year $t$ to measure credit risk;

- $L L P_{b, t-1}$ is the lagged loan loss provision to total gross loans ratio of bank $b$ at year $t-1$ to consider the persistency of bank credit risk, as proposed by Delis and Kouretas (2011) ;

- $\Pi_{b, t}$ is the profitability proxy (either ROAA, NIM, PTP or $C T I$, see Section 4) of bank $b$ at year $t$;

- $\Pi_{b, t-1}$ is the lagged profitability proxy (either ROAA, NIM, PTP or $C T I$ ) of bank $b$ at year $t-1$ to leave open the possibility for profitability to adjust over time, as suggested by Claessens et al. (2018) ;

- $M P 1_{t}$ is the monetary policy index included in the credit risk equation at year $t$, namely either EURIBOR-1M or EURIBOR-6M ;

- $M P 2_{t}$ is the monetary policy index included in the profitability equation at year $t$, namely either Spread:10Y-3M or Spread:10Y-6M ;

- $E D C 1_{b, t-1}$ are the endogenous controls included in the credit risk equation of bank $b$ at year $t-1$ (see Table 4 to Table 9) ;

- $E D C 2_{b, t-1}$ are the endogenous controls included in the profitability equation of bank $b$ at year $t-1$ (see Table 4 to Table 9) ;

- Real GDP $P_{t}$ is the macroeconomic control variable at year $t$ gauging the annual percentage change on previous year in a country's real gross domestic product.

We estimate System (1) using generalized method of moments (GMM), which is robust to the distribution of errors and which 
Table 1: Definitions.

\begin{tabular}{|c|c|c|}
\hline Variable & Methodological approach & Data source \\
\hline \multicolumn{3}{|l|}{ Panel A: Variables of interest } \\
\hline LLP & $\begin{array}{l}\text { Loan loss provision over a bank's total gross loans as the ability to absorb losses from non-performing loans in its balance sheet (determining the quality } \\
\text { of its loans). }\end{array}$ & Fitch Connect \\
\hline Zscore & $\begin{array}{l}\text { Natural logarithm of the following ratio: the sum of ROAA and Equity to the numerator, and the standard deviation of ROAA to the denominator. It } \\
\text { relates a bank's capital level to variability in its returns, indicating how much variability in returns can be absorbed by capital without the bank becoming } \\
\text { insolvent. It acts as a an accounting-based measure of the distance to default (see also Equation 2). }\end{array}$ & Fitch Connect \\
\hline ROAA & Return on average assets as the net income over a bank's average total assets. & Fitch Connect \\
\hline NIM & $\begin{array}{l}\text { Net interest margin as the difference between interest income (i.e., gross interest and dividend income) and interest expense over a bank's total earning } \\
\text { assets (i.e., total loans, total securities, investments in property and earning assets not otherwise categorized). }\end{array}$ & Fitch Connect \\
\hline PTP & Pre-tax profit over a bank's total assets. & Fitch Connect \\
\hline $\mathrm{CTI}$ & Cost to income ratio as total operating costs (including administrative and fixed costs) over a bank's total operating income. & Fitch Connect \\
\hline EURIBOR-1M & $\begin{array}{l}\text { Benchmark rate at which euro interbank 1-month term deposits are offered by prime banks to one another. It acts as a representative short-term interest } \\
\text { rate series for domestic money markets. }\end{array}$ & Eurostat \\
\hline EURIBOR-6M & $\begin{array}{l}\text { Benchmark rate at which euro interbank 6-month term deposits are offered by prime banks to one another. It acts as a representative medium-term interest } \\
\text { rate series for domestic money markets. }\end{array}$ & Eurostat \\
\hline Spread:10Y-3M & $\begin{array}{l}\text { Difference between a central government bond yield on the secondary market with } 10 \text { years' residual maturity and its 3-month implied sovereign bond } \\
\text { yield. }\end{array}$ & Thompson Reuters Eikon \\
\hline Spread:10Y-6M & $\begin{array}{l}\text { Difference between a central government bond yield on the secondary market with } 10 \text { years' residual maturity and its } 6 \text {-month implied sovereign bond } \\
\text { yield. }\end{array}$ & Thompson Reuters Eikon \\
\hline \multicolumn{3}{|l|}{ Panel B: Bank-level controls } \\
\hline Size & Natural logarithm of a bank's total assets as a measure of its size. & Fitch Connect \\
\hline Equity & Total equity over a bank's total assets as a measure of its capital adequacy. & Fitch Connect \\
\hline Net loans & Net loans over a bank's total assets as a measure of its commitment to traditional financial intermediation. & Fitch Connect \\
\hline Liquid assets & $\begin{array}{l}\text { Liquid assets (including cash, reserves representing surplus, securities and interbank loans with very short maturity) over a bank's total assets as a measure } \\
\text { of its level of liquidity. }\end{array}$ & Fitch Connect \\
\hline \multicolumn{3}{|l|}{ Panel C: Macroeconomic controls } \\
\hline $\begin{array}{l}\text { Real GDP } \\
\text { Recession }\end{array}$ & $\begin{array}{l}\text { Annual percentage change on previous year in a country's real gross domestic product (in volume). } \\
\text { Dummy variable that equals } 1 \text { when Real GDP is negative, and } 0 \text { otherwise. }\end{array}$ & $\begin{array}{l}\text { Eurostat } \\
\text { Eurostat }\end{array}$ \\
\hline \multicolumn{3}{|l|}{ Panel D: Bank classifications } \\
\hline Cooperative banks & Retail \& Consumer banks, Universal Commercial banks and Wholesale Commercial banks displaying a cooperative ownership structure. & EACB (2020a) \\
\hline Non-cooperative banks & Retail \& Consumer banks, Universal Commercial banks and Wholesale Commercial banks displaying a non-cooperative ownership structure. & Fitch Connect \\
\hline Consolidated cooperative banks & Cooperative banks displaying a number of clients per branch above the full sample median in 2019 . & EACB (2020b) \\
\hline Relationship-based cooperative banks & Cooperative banks displaying a number of clients per branch below the full sample median in 2019. & EACB (2020b) \\
\hline
\end{tabular}

accounts for the heteroskedasticity of errors (Ullah et al., 2018). We also include in the regressions cross-sectional fixed effects and heteroskedasticity-robust standard errors clustered at the bank level. As previous empirical studies of credit risk and profitability highlight the potential endogeneity with most banklevel controls ${ }^{9}$, we follow the methodology of Distinguin et al. (2013) by instrumenting all the bank-level explanatory variables (i.e., $E D C 1$ in the credit risk equation and EDC2 in the profitability equation) by their one-year lagged value. While the two variables of interest (i.e., credit risk and profitability) are not lagged, using a simultaneous GMM equations system addresses endogeneity issues. As both bank-level controls and bank fixed effects enable us to control for each bank's credit risk and profitability, the results of our estimations can be interpreted as the direct effects of a change in monetary policy on banks' credit risk and profitability. In addition, the regressions of credit risk and profitability both control for general economic conditions (through the Real GDP variable) to further acknowledge the difficulty in addressing endogeneity in monetary policy.

On the one hand, in the credit risk equation (see the results in Table 4 to Table 8), the dependent variable is measured by the ratio of loan loss provision to total gross loans, which reflects banks' credit risk profiles. The robustness checks in Table 9 also include a measure of banks' overall risk using the Z-score index (IJtsma et al., 2017). These two choices of bank risk proxies are guided by Khan et al. (2017) and Houston et al. (2010). The Z-score represents the number of standard deviations below the

\footnotetext{
${ }^{9}$ For each equation of System (1), we run the Hausman test to confirm the presence of endogeneity both in the credit risk and in the profitability equations.
}

mean by which profits would have to fall to deplete the bank's equity capital. Despite being widely used in the literature (Delis et al., 2014; Ramayandi et al., 2014), a high Z-score indicates lower overall risk-taking by a bank (i.e., greater stability). As a measure of the distance from insolvency (Laeven and Levine, 2009), this is computed as follows:

$$
Z_{\text {score }_{b, t}}=\frac{\text { ROAA }_{b, t}+\text { Equity }_{b, t}}{(\text { Standard deviation of } R O A A)_{b}}
$$

Where:

- $R O A A_{b, t}$ equals the return on average assets of bank $b$ at year $t$;

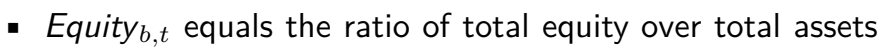
of bank $b$ at year $t$;

- Standard deviation of $R O A A_{b}$ equals the standard deviation of asset returns of bank $b$ over the full sample period.

The bank-level controls in the credit risk equation are the bank characteristics and activities commonly adopted in the literature. Similarly to Dinger and te Kaat (2020); Abbate and Thaler (2019) and Khan et al. (2017), we consider the natural logarithm of total assets (Size) as well as the ratio of net loans to total assets (Net loans) as potential determinants of credit risk (in addition to the profitability proxies described hereafter). To gauge the monetary policy stance within the credit risk equation, we employ two maturities (1-month and 6-month maturities) of the benchmark rate at which euro interbank term deposits are offered by prime banks to one another (EURIBOR-1M and EURIBOR-6M, respectively). These respectively represent the short- and medium-term interest rate series for domestic 
Table 2: Full sample descriptive statistics and bank variables' correlations.

\begin{tabular}{|c|c|c|c|c|c|c|c|c|c|c|}
\hline \multicolumn{10}{|c|}{ Panel A: Descriptive statistics } & Countries \\
\hline \multicolumn{11}{|c|}{ Bank-level variables } \\
\hline LLP & & $\%$ & 0.419 & 0.230 & 0.830 & -1.010 & 2.630 & 30,467 & 3,998 & 10 \\
\hline Zscore & & std. dev. & 4.668 & 4.312 & 3.351 & 0.987 & 41.875 & 30,135 & 3,941 & 10 \\
\hline ROAA & & $\%$ & 0.368 & 0.280 & 0.448 & -0.490 & 1.850 & 30,467 & 3,998 & 10 \\
\hline NIM & & $\%$ & 2.085 & 2.150 & 0.731 & 0.200 & 3.380 & 30,467 & 3,998 & 10 \\
\hline PTP & & $\%$ & 0.571 & 0.490 & 0.557 & -0.530 & 2.400 & $\begin{array}{l}30,467 \\
30,40\end{array}$ & 3,998 & 10 \\
\hline CTI & & $\%$ & 69.040 & 68.690 & 13.698 & 39.270 & 99.430 & 30,467 & 3,998 & 10 \\
\hline Size & & $\ln (€)$ & 20.375 & 20.225 & 1.708 & 17.451 & 23.860 & 30,467 & 3,998 & 10 \\
\hline Equity & & $\%$ & 10.019 & 8.790 & 5.914 & 3.660 & 37.650 & 30,467 & 3,998 & 10 \\
\hline Net loans & & $\%$ & 58.204 & 60.810 & 18.682 & 8.540 & 86.760 & 30,467 & 3,998 & 10 \\
\hline Liquid assets & & $\%$ & 16.110 & 11.390 & 14.189 & 2.270 & 63.390 & 30,467 & 3,998 & 10 \\
\hline \multicolumn{11}{|c|}{ Country-level variables } \\
\hline EURIBOR-1M & & $\%$ & 0.114 & 0.130 & 0.472 & -0.400 & 1.180 & 30,467 & 3,998 & 10 \\
\hline EURIBOR-6M & & $\%$ & 0.371 & 0.310 & 0.614 & -0.300 & 1.640 & 30,467 & 3,998 & 10 \\
\hline Spread:10Y-3M & & $\%$ & 1.537 & 1.242 & 1.124 & -0.270 & 10.292 & 30,467 & 3,998 & 10 \\
\hline Spread:10Y-6M & & $\%$ & 1.383 & 0.999 & 1.003 & -1.010 & 10.049 & 30,467 & 3,998 & 10 \\
\hline Real GDP & & $\%$ & 1.537 & 1.500 & 1.488 & -4.100 & 4.900 & 30,467 & 3,998 & 10 \\
\hline Recession & & $\{0,1\}$ & 0.059 & 0.000 & 0.237 & 0.000 & 1.000 & 30,467 & 3,998 & 10 \\
\hline \multicolumn{11}{|c|}{ Panel B: Bank-level variables' correlations } \\
\hline & LLP & Zscore & ROAA & NIM & PTP & CTI & Size & Equity & Net loans & Liquid assets \\
\hline LLP & 1.000 & & & & & & & & & \\
\hline Zscore & -0.023 & 1.000 & & & & & & & & \\
\hline ROAA & -0.100 & 0.072 & 1.000 & & & & & & & \\
\hline NIM & 0.085 & 0.022 & 0.055 & 1.000 & & & & & & \\
\hline PTP & -0.144 & 0.100 & 0.958 & 0.130 & 1.000 & & & & & \\
\hline CTI & -0.174 & 0.011 & -0.314 & -0.156 & -0.361 & 1.000 & & & & \\
\hline Size & -0.009 & -0.088 & -0.088 & -0.289 & -0.084 & -0.251 & 1.000 & & & \\
\hline Equity & 0.070 & 0.204 & 0.377 & 0.021 & 0.362 & -0.000 & -0.312 & 1.000 & & \\
\hline Net loans & -0.070 & -0.066 & -0.084 & 0.273 & -0.064 & -0.131 & 0.140 & -0.202 & 1.000 & \\
\hline Liquid assets & -0.050 & 0.034 & 0.098 & -0.318 & 0.047 & 0.178 & -0.107 & 0.163 & -0.585 & 1.000 \\
\hline
\end{tabular}

money markets affecting credit risk management by euro area banks. We control for the macroeconomic conditions using the Real GDP variable in the credit risk equation.

On the other hand, following Elekdag et al. (2020) and Altavilla et al. (2018), we use four indicators of profitability in the profitability equation described in the second part of System (1):

- $R O A A_{b, t}$, the return on average assets of bank $b$ in year $t$. The higher this index, the better is bank profitability;

- $N / M_{b, t}$, the net interest margin of bank $b$ in year $t$. The higher this index, the better is bank profitability;

- $P T P_{b, t}$, the pretax profit over total assets of bank $b$ in year $t$. The higher this index, the better is bank profitability;

- $C T I_{b, t}$, the cost to income ratio of bank $b$ in year $t$. As increases in this index imply lower bank profitability, whereas increases in the other profitability proxies represent higher bank profitability, we multiply the values for this ratio by -1 to provide a more consistent interpretation among the profitability proxies. In other words, a higher value indicates greater profitability in all instances. Hereafter, we use the $-C T I$ variable name to refer to the bank cost to income ratio.

Based on Claessens et al. (2018), we additionally use the ratios of total equity to total assets (Equity) and total liquid assets to total assets (Liquid assets) as the bank-level controls affecting profitability. We also proxy for monetary policy in the profitability equation using the slope of the yield curve between 10-year government bond yields and 3-month (6-month) implied sovereign bond yields accounted for by the Spread:10Y-3M variable (Spread:10Y-6M). Similarly to the credit risk equation, we control for the business cycle using the Real GDP variable in the profitability equation.

\section{Data and sample}

We assemble a unique dataset from different sources to investigate the impact of monetary policy on banks' credit risk and profitability depending on whether they display a cooperative ownership structure and, if so, whether they are committed to relationship lending. Table 1 lists the variables used in the empirical analysis along with the methodological approaches and data sources. Panel A summarizes the variables of interest on credit risk, profitability, and the monetary policy stance. Panel B covers bank-level controls and panel $\mathrm{C}$ macroeconomic controls. Panel D describes the four subsamples used in the study, namely, cooperative banks, non-cooperative banks, consolidated cooperative banks, and relationship-based cooperative banks.

Unconsolidated bank-level balance sheets and income statements are collected from Fitch Connect at an annual frequency, and these include three categories of banks: Retail \& Consumer, Universal Commercial, and Wholesale Commercial. To address the potential of outliers to distort the results, all the banklevel variables are winsorized at the $5^{t h}$ and $95^{t h}$ percentiles, thresholds commonly accepted in the literature (Beltratti and Stulz, 2012). The final dataset consists of 30,467 observations from 3,998 banks in 10 euro area countries ${ }^{10}$ between 2010 and 2019. Table 2 reports the descriptive statistics of the bank- and country-level variables for the full sample (panel A) as well as the Pearson correlations of the bank-level variables (panel $B$ ).

\footnotetext{
${ }^{10}$ Austria, Finland, France, Germany, Italy, Luxembourg, the Netherlands, Portugal, Slovenia, and Spain.
} 
We do not find the bank indicators employed as explanatory variables to be highly correlated, so multicollinearity is not a major concern in the estimations. The correlation coefficients of credit risk, $L L P$, with the profitability proxies, ROAA, NIM, $P T P$, and $C T I$, are $-0.100,0.085,-0.144$, and -0.174 , respectively. Table 3 refines the summary statistics by dividing the full sample into the four subsamples described above.

Bank risk-taking is gauged by two indexes: $L L P$ for credit risk (see Table 4 to Table 8) and Z-score for overall risk (see the robustness checks in Table 9). The mean $L L P$ for the full sample is $0.419 \%$, with a standard deviation of $0.830 \%$. Interestingly, Table 3 indicates that, on average, non-cooperative banks display higher LLP (as well as a higher standard deviation) than cooperative banks in the euro area between 2010 and 2019. While both consolidated and relationship-based cooperative banks exhibit, on average, lower $L L P$ than non-cooperative banks, there is no significant difference between the two groups of cooperative banks in terms of the average $L L P$. The full sample mean Z-score is 4.668 , with a standard deviation of 3.351. Table 3 shows that, on average, the overall risk of noncooperative banks is significantly lower (i.e., with a greater Zscore value) - although much more volatile-than cooperatives'. Relationship-based cooperative banks perform significantly better regarding overall risk than consolidated cooperative banks.

Bank profitability is measured by four indicators, namely, ROOA, NIM, PTP, and CTI, with the latter having the highest standard deviation. The means are, respectively, $0.368 \%$, $2.085 \%, 0.571 \%$, and $69.040 \%$. On average, cooperative banks fare significantly better in terms of NIM, which might be linked to their higher share of net loans to total assets (59.330\% on average) relative to non-cooperatives' (mean value of $56.966 \%$ ). In addition, the NIM index is significantly higher for relationship-based cooperative banks (mean value of $2.281 \%$ ) than for consolidated cooperative banks $(1.663 \%$ on average). Alternatively, consolidated cooperative banks, on average, gain better results than relationship-based cooperative banks for ROAA $(0.399 \%$ vs. $0.337 \%)$, PTP $(0.578 \%$ vs. $0.528 \%)$, and CTI $(66.170 \%$ vs. $69.444 \%)$. Specifically, the differences in CTI between consolidated and relationship-based cooperative banks most likely reflect the higher costs required to set up and maintain decentralized branch networks.

As expected, non-cooperative banks are significantly larger than cooperative banks on average $(4.370 €$ billion vs. $1.670 €$ billion), while consolidated cooperative banks ( $11.300 €$ billion) are larger than relationship-based cooperative banks $(0.869 €$ billion). The full sample mean Equity is $10.019 \%$, with a standard deviation of $5.914 \%$. Non-cooperative banks are better capitalized (mean value of $10.523 \%$ ) than cooperative banks $(9.561 \%)$, which might reflect the fact that cooperative banks are more involved in traditional financial intermediation, while non-cooperative banks engage more in capital market transactions to fund themselves in wholesale markets (Claessens et al.,
2018). Interestingly, relationship-based cooperative banks display significantly better capitalization levels $(9.579 \%$ on average) than consolidated cooperative banks (9.347\%). In turn, the mean proportions of Net loans and Liquid assets in banks' total assets are, respectively, 58.204\% and $16.110 \%$; the former is slightly more volatile $(18.682 \%)$ than the latter $(14.189 \%)$. On average, cooperative banks hold a higher share of loans (59.330\%) than non-cooperatives' $(56.966 \%)$, as do consolidated cooperative banks $(67.003 \%)$ compared with relationshipbased cooperative banks (58.690\%). Regarding the mean levels of liquid assets in the euro area, non-cooperative banks outperform ( $17.396 \%$ of total assets) cooperative banks (14.941\%) between 2010 and 2019, while consolidated cooperative banks (16.352\% of total assets) outperform relationship-based cooperative banks $(14.823 \%)$.

We next collect from Eurostat the yearly averages of the euro interbank offered rates at which 1-month (EURIBOR-1M) and 6-month (EURIBOR-6M) term deposits are offered by prime banks to one another. We also collect the annual percentage changes in countries' real gross domestic product (Real $G D P$ ) compared with the previous year. Thompson Reuters Eikon provide the data on the spreads (i.e., slopes of the yield curve) between central governments' bond yield in the secondary market with 10 years' residual maturity as well as the 3-month (Spread:10Y-3M) and 6-month (Spread:10Y-6M) implied sovereign bond yields. The averages of EURIBOR1M, EURIBOR-6M, Spread:10Y-3M, Spread:10Y-6M, and Real GDP are $0.114 \%, 0.371 \%, 1.537 \%, 1.383 \%$, and $1.537 \%$, respectively. Understandably, monetary policy indexes based on spreads over longer periods display higher standard deviations (1.124\% for Spread:10Y-3M vs. $1.003 \%$ for Spread:10Y-6M). In turn, Real GDP varies considerably across the observations, with a low of $-4.100 \%$ and a high of $4.900 \%$ over the full sample period and a standard deviation of $1.488 \%$.

To explore the different impacts of monetary policy on bank credit risk and profitability by ownership structure, a bank is classified as a cooperative if it displays a cooperative ownership structure as defined by EACB (2020a) and a non-cooperative otherwise. In addition, we examine the different impacts of monetary policy on bank credit risk and profitability depending on banks' commitment to relationship lending (Agarwal et al., 2018) by distinguishing consolidated cooperative banks from relationship-based cooperative banks (Groeneveld, 2017). As described in Table A2, a cooperative bank is considered to be relationship-based (i.e., have wider geographic coverage and closer customer relationships) if the number of clients per branch is below the 2019 median value (i.e., 3413 clients per branch) computed on the basis of EACB (2020b) data ${ }^{11}$.

\footnotetext{
${ }^{11}$ These data are elaborated by Tilburg University and based on inputs of the members of the European Association of Cooperative Banks. The list of full members is available from http://www.eacb.coop/en/about/membership/full-members.html.
} 
Table 3: Summary statistics of cooperative, non-cooperative, consolidated cooperative and relationship-based cooperative banks' variables.

\begin{tabular}{|c|c|c|c|c|c|c|c|c|c|c|}
\hline & LLP & Zscore & ROAA & NIM & PTP & CTI & $\begin{array}{l}\text { Total assets } \\
\text { (€ billion) }\end{array}$ & Equity & Net loans & Liquid assets \\
\hline \multicolumn{11}{|c|}{ Panel A: Cooperative banks } \\
\hline Mean & 0.402 & 4.511 & 0.342 & 2.234 & 0.532 & 69.192 & 1.670 & 9.561 & 59.330 & 14.941 \\
\hline Median & 0.250 & 4.399 & 0.300 & 2.240 & 0.520 & 68.970 & 0.316 & 9.070 & 60.190 & 11.340 \\
\hline Std. dev. & 0.779 & 1.688 & 0.294 & 0.536 & 0.368 & 11.082 & 4.320 & 3.189 & 14.024 & 11.485 \\
\hline Min. & -1.010 & 1.285 & -0.490 & 0.200 & -0.530 & 39.270 & 0.038 & 3.660 & 8.540 & 2.270 \\
\hline Max. & 2.630 & 41.875 & 1.850 & 3.380 & 2.400 & 99.430 & 23.000 & 37.650 & 86.760 & 63.390 \\
\hline \multicolumn{11}{|c|}{ Panel B: Non-cooperative banks } \\
\hline Mean & 0.437 & 4.843 & 0.396 & 1.922 & 0.613 & 68.873 & 4.370 & 10.523 & 56.966 & 17.396 \\
\hline Median & 0.210 & $\begin{array}{l}4.045 \\
4.136\end{array}$ & 0.230 & 2.020 & 0.450 & 68.320 & 1.410 & 8.380 & 61.780 & 11.450 \\
\hline Std. dev. & 0.883 & 4.529 & 0.570 & 0.870 & 0.707 & 16.090 & 6.780 & 7.860 & 22.665 & 16.569 \\
\hline Min. & -1.010 & 0.987 & -0.490 & 0.200 & -0.530 & 39.270 & 0.038 & 3.660 & 8.540 & 2.270 \\
\hline Max. & 2.630 & 41.617 & 1.850 & 3.380 & 2.400 & 99.430 & 23.000 & 37.650 & 86.760 & 63.390 \\
\hline Test $t$-statistic ${ }^{a}$ & $3.717^{* * *}$ & $8.576^{* * *}$ & $10.597^{* * *}$ & $-37.962^{* * *}$ & $12.748^{* * *}$ & $-2.029 * *$ & $41.809 * * *$ & $14.231^{* * *}$ & $-11.055 * * *$ & $15.141^{* * *}$ \\
\hline \multicolumn{11}{|c|}{ Panel C: Consolidated cooperative banks } \\
\hline Mean & 0.372 & 4.299 & 0.399 & 1.663 & 0.578 & 66.170 & 11.300 & 9.347 & 67.003 & 16.352 \\
\hline Median & 0.240 & 4.416 & 0.400 & 1.600 & 0.560 & 64.970 & 11.200 & 8.745 & 72.325 & 13.820 \\
\hline Std. dev. & 0.593 & 0.858 & 0.324 & 0.541 & 0.444 & 11.708 & 8.450 & 3.674 & 14.550 & 10.262 \\
\hline Min. & -1.010 & 1.788 & -0.490 & 0.200 & -0.530 & 39.270 & 0.038 & 3.660 & 8.540 & 2.270 \\
\hline Max. & 2.630 & 6.435 & 1.850 & 3.380 & 2.170 & 99.430 & 23.000 & 37.650 & 86.760 & 63.390 \\
\hline Test $t$-statistic $\boldsymbol{b}$ & $2.519^{* *}$ & $4.194^{* * *}$ & -0.165 & $10.301^{* * *}$ & $1.700^{*}$ & $5.761^{* * *}$ & $-33.805 * * *$ & $5.199 * * *$ & $-15.255 * * *$ & $2.172^{* *}$ \\
\hline \multicolumn{11}{|c|}{ Panel D: Relationship-based cooperative banks } \\
\hline Mean & 0.404 & 4.529 & 0.337 & 2.281 & 0.528 & 69.444 & 0.869 & 9.579 & 58.690 & 14.823 \\
\hline Median & 0.250 & 4.396 & 0.300 & 2.280 & 0.510 & 69.270 & 0.285 & 9.080 & 59.600 & 11.020 \\
\hline Std. dev. & 0.793 & 1.738 & 0.290 & 0.508 & 0.360 & 10.991 & 2.420 & 3.145 & 13.788 & 11.574 \\
\hline Min. & -1.010 & 1.285 & -0.490 & 0.200 & -0.530 & 39.270 & 0.038 & 3.660 & 8.540 & 2.270 \\
\hline Max. & 2.630 & 41.875 & 1.850 & 3.380 & 2.400 & 99.430 & 23.000 & 37.650 & 86.760 & 63.390 \\
\hline Test $t$-statistic $c$ & -1.370 & $-4.590^{* * *}$ & $7.103^{* * *}$ & $-40.823^{* * *}$ & $4.607 * * *$ & $-9.979 * * *$ & $106.647^{* * *}$ & $-2.453^{* *}$ & $20.210^{* * *}$ & $4.486^{* * *}$ \\
\hline Test $t$-statistic d & $3.359^{* * *}$ & $7.808^{* * *}$ & $11.195^{* * *}$ & $-43.164^{* * *}$ & $13.000^{* * *}$ & $-3.547 * * *$ & $59.025^{* * *}$ & $13.525^{* * *}$ & $-7.875^{* * *}$ & $15.411^{* * *}$ \\
\hline
\end{tabular}

Branches' centralization strategies used to reduce a bank's territorial coverage are usually based on medium-term decisions and require time to be implemented (the closure of local branches and internal restructuring do not happen overnight). Accordingly, we assume that our sample period is sufficiently short to consider which centralization strategies observed in 2019 (i.e., the year in which the most recent data are available from the European Association of Co-operative Banks) have been relatively steady for each cooperative group in the sample since 2010. Therefore, the categorizations of cooperative banks in 2019 are considered to represent their strategic decisions taken in 2010.

For brevity, we use LLP, Z-score, ROAA, NIM, PTP, -CTI, Size, Equity, Net loans, Liquid assets, EURIBOR1M, EURIBOR-6M, Spread:10Y-3M, Spread:10Y-6M, and Real $G D P$ to refer to the loan loss provision to gross loans ratio, natural logarithm of the Z-score index, return on average assets ratio, net interest margin, pretax profit to total assets ratio, cost to income ratio, natural logarithm of total assets, ratio of equity to total assets, ratio of net loans to total assets, ratio of liquid assets to total assets, benchmark rate at which euro interbank 1-month term deposits are offered, benchmark rate at which euro interbank 6-month term deposits are offered, difference between 10-year government bond yields and 3-month implied sovereign bond yields, difference between 10-year government bond yields and 6-month implied sovereign bond yields, and annual percentage change in a country's real GDP from the previous year, respectively.

\section{Main findings}

To test the effects of expansionary monetary policy on bank credit risk and profitability depending on whether banks display a cooperative ownership structure and, if so, whether they are committed to relationship lending, we estimate System (1). In the credit risk equation, we regress the loan loss provision ratio on profitability, the monetary policy index, and a set of determinants commonly used in the literature. We use four indicators of bank profitability: ROAA, NIM, PTP, and -CTI. In the profitability equation, we regress one by one our four proxies of bank profitability on the credit risk indicator, the measure of monetary policy, and a set of explanatory variables outlined in the literature. The presumably endogenous bank-level indicators are instrumented by their one-year lagged value. Regarding our two variables of interest (i.e., credit risk and profitability), which are not lagged, we address the endogeneity issue by estimating a dynamic simultaneous equations system using GMM techniques.

\subsection{The effects of a low interest rate environment on credit risk and profitability: preliminary results}

We first examine the effect of a low interest rate environment on credit risk and profitability for the full sample. Table 4 reports the GMM dynamic panel regression results from System (1). The significant and negative signs of both EURIBOR$1 M$ and EURIBOR-6M in the credit risk equation confirm the presence of a risk-taking channel of monetary policy (Altunbas et al., 2014) in the euro area between 2010 and 2019. Here, the risk-taking channel is slightly more intense when based on the medium-term EURIBOR-6M rate than on theEURIBOR-1M 
Table 4: Credit risk and profitability in a low interest rate environment (2010-2019).

\begin{tabular}{|c|c|c|c|c|c|c|c|c|}
\hline & (1) & (2) & (3) & (4) & (5) & (6) & (7) & (8) \\
\hline \multicolumn{9}{|c|}{ Credit risk equation } \\
\hline LLP lagged & $\begin{array}{l}0.563^{* * *} \\
(54.765)\end{array}$ & $\begin{array}{l}0.561^{* * *} \\
(57.196)\end{array}$ & $\begin{array}{l}0.555^{* * *} \\
(52.812)\end{array}$ & $\begin{array}{l}0.550 * * * \\
(56.364)\end{array}$ & $\begin{array}{l}0.563^{* * *} \\
(55.040)\end{array}$ & $\begin{array}{l}0.561 * * * \\
(57.503)\end{array}$ & $\begin{array}{l}0.559 * * * \\
(53.092)\end{array}$ & $\begin{array}{l}0.550^{* * *} \\
(56.619)\end{array}$ \\
\hline ROAA & $\begin{array}{l}(54.765) \\
-0.146 * * \\
(-8.284)\end{array}$ & $(57.196)$ & $(52.812)$ & $(56.364)$ & $\begin{array}{l}(55.040) \\
-0.147 * * * \\
(-8.318)\end{array}$ & $(57.503)$ & (53.092) & (56.619) \\
\hline NIM & & $\begin{array}{l}0.039^{* * *} \\
(4.435)\end{array}$ & & & & $\begin{array}{l}0.042^{* * *} \\
(4.728)\end{array}$ & & \\
\hline PTP & & & $\begin{array}{l}-0.149 * * * \\
(-9.931)\end{array}$ & & & & $\begin{array}{l}-0.149 * * * \\
(-9.941)\end{array}$ & \\
\hline$-\mathrm{CTI}$ & & & & $\begin{array}{l}0.007 * * * \\
(-15.359)\end{array}$ & & & & $\begin{array}{l}0.007 * * * \\
(-15.453)\end{array}$ \\
\hline Size & $\begin{array}{l}-0.002 \\
(-0.830)\end{array}$ & $\begin{array}{l}0.007 * * \\
(2.291)\end{array}$ & $\begin{array}{l}-0.003 \\
(-1.109)\end{array}$ & $\begin{array}{l}-0.011 * * * \\
(-4.114)\end{array}$ & $\begin{array}{l}-0.002 \\
(-0.880)\end{array}$ & $\begin{array}{l}0.007 * * \\
(2.379)\end{array}$ & $\begin{array}{l}-0.003 \\
(-1.154)\end{array}$ & $\begin{array}{l}-0.011^{* * * *} \\
(-4.180)\end{array}$ \\
\hline Net loans & $\begin{array}{l}-0.001 * * * \\
(-4.014)\end{array}$ & $\begin{array}{l}-0.002^{* * *} \\
(-5.221)\end{array}$ & $\begin{array}{l}-0.001 * * * \\
(-3.893)\end{array}$ & $\begin{array}{l}-0.002^{* * *} \\
(-5.184)\end{array}$ & $\begin{array}{l}-0.001 * * * \\
(-3.992)\end{array}$ & $\begin{array}{l}-0.002^{* * *} \\
(-5.299)\end{array}$ & $\begin{array}{l}-0.001 * * * \\
(-3.870)\end{array}$ & $\begin{array}{l}-0.002 * * * \\
(-5.171)\end{array}$ \\
\hline EURIBOR-1M & $\begin{array}{l}-0.021^{* * *} \\
(-2.575)\end{array}$ & $\begin{array}{l}-0.027 * * * \\
(-3.072)\end{array}$ & $\begin{array}{l}-0.017 * * \\
(-2.037)\end{array}$ & $\begin{array}{l}-0.032 * * * \\
(-3.784)\end{array}$ & & & & \\
\hline EURIBOR-6M & & & & & $\begin{array}{l}-0.027 * * * \\
(-4.392)\end{array}$ & $\begin{array}{l}-0.033^{* * *} \\
(-4.927)\end{array}$ & $\begin{array}{l}-0.024^{* * *} \\
(-3.767)\end{array}$ & $\begin{array}{l}-0.036 * * * \\
(-5.579)\end{array}$ \\
\hline Real GDP & $\begin{array}{l}-0.132 * * * \\
(-37.468)\end{array}$ & $\begin{array}{l}-0.134 * * * \\
(-37.250)\end{array}$ & $\begin{array}{l}-0.130 * * * \\
(-37.199)\end{array}$ & $\begin{array}{l}-0.132 * * * \\
(-37.006)\end{array}$ & $\begin{array}{l}-0.133 * * * \\
(-37.227)\end{array}$ & $\begin{array}{l}-0.135 * * * \\
(-37.111)\end{array}$ & $\begin{array}{l}-0.130 * * * \\
(-36.950)\end{array}$ & $\begin{array}{l}-0.132 * * * \\
(-36.876)\end{array}$ \\
\hline \multicolumn{9}{|c|}{ Profitability equation } \\
\hline ROAA lagged & $\begin{array}{l}0.695 * * \\
(57.994)\end{array}$ & & & & $\begin{array}{l}0.695 * * * \\
(57.974)\end{array}$ & & & \\
\hline NIM lagged & & $\begin{array}{l}0.896 * * * \\
(199.297)\end{array}$ & & & & $\begin{array}{l}0.898 * * * \\
(200.791)\end{array}$ & & \\
\hline PTP lagged & & & $\begin{array}{l}0.711^{* * *} \\
(61.656)\end{array}$ & & & & $\begin{array}{l}0.710^{* * *} \\
(61.686)\end{array}$ & \\
\hline -CTI lagged & & & & $\begin{array}{l}0.771^{* * *} \\
(100.513)\end{array}$ & & & & $\begin{array}{l}0.7711^{* * *} \\
(100.336)\end{array}$ \\
\hline LLP & $\begin{array}{l}-0.052 * * * \\
(-12245)\end{array}$ & $\begin{array}{l}0.012^{* * *} \\
(3.401)\end{array}$ & $\begin{array}{l}-0.076 * * * \\
(-14.441)\end{array}$ & $\begin{array}{l}0.898^{* * *} \\
(-91108)\end{array}$ & $\begin{array}{l}-0.053 * * * \\
(-12082)\end{array}$ & $\begin{array}{l}0.012^{* * *} \\
(3.496)\end{array}$ & $\begin{array}{c}-0.078^{* * *} \\
(-14.167)\end{array}$ & $0.921^{* * *}$ \\
\hline Equity & $0.008^{* * *}$ & 0.000 & $0.009 * * *$ & -0.015 & $0.008^{* * * *}$ & 0.000 & $0.009 * * *$ & -0.016 \\
\hline & $(10.557)$ & $(0.699)$ & $(10.146)$ & $(1.076)$ & $(10.551)$ & $(0.566)$ & $(10.129)$ & $(1.187)$ \\
\hline Liquid assets & $\begin{array}{l}0.000 \\
(1.391)\end{array}$ & $\begin{array}{l}-0.001 * * * \\
(-4887)\end{array}$ & $\begin{array}{l}-0.000 \\
(-1.013)\end{array}$ & $\begin{array}{l}-0.042 * * * \\
(7685)\end{array}$ & $\begin{array}{l}0.000 \\
(1.408)\end{array}$ & $\begin{array}{l}-0.001^{* * *} \\
(-4.689)\end{array}$ & $\begin{array}{l}-0.000 \\
(-0.992)\end{array}$ & $-0.042^{* * * *}$ \\
\hline Spread:10Y-3M & $\begin{array}{l}0.010^{* * *} \\
(3.777)\end{array}$ & $\begin{array}{l}0.027 * * * \\
(11.825)\end{array}$ & $\begin{array}{l}0.012^{* * *} \\
(3.826)\end{array}$ & $\begin{array}{l}0.664 * * * \\
(-9.821)\end{array}$ & & & & \\
\hline Spread:10Y-6M & & & & & $\begin{array}{l}0.014 * * * \\
(4.141)\end{array}$ & $\begin{array}{l}0.023 * * * \\
(8.864)\end{array}$ & $\begin{array}{l}0.016 * * * \\
(3.865)\end{array}$ & $\begin{array}{l}0.559 * * * \\
(-7.010)\end{array}$ \\
\hline Real GDP & $\begin{array}{l}0.004 * * \\
(2.167)\end{array}$ & $\begin{array}{l}0.015^{* * *} \\
(9.278)\end{array}$ & $\begin{array}{l}0.008^{* * *} \\
(3.836)\end{array}$ & $\begin{array}{l}0.064 \\
(-1.351)\end{array}$ & $\begin{array}{l}0.005^{* * *} \\
(2.692)\end{array}$ & $\begin{array}{l}0.012 * * * \\
(7.644)\end{array}$ & $\begin{array}{l}0.009^{* * *} \\
(4.151)\end{array}$ & $\begin{array}{l}-0.017 \\
(0.365)\end{array}$ \\
\hline Observations & 26,146 & 26,146 & 26,146 & 26,146 & 26,146 & 26,146 & 26,146 & 26,146 \\
\hline Banks & 3,998 & 3,998 & 3,998 & 3,998 & 3,998 & 3,998 & 3,998 & 3,998 \\
\hline
\end{tabular}

Notes: This table reports the results of estimating dynamic simultaneous equations System (1) using two-step GMM for an unbalanced panel of European Retail \& Consumer, Universal Commercial and Wholesale Commercial banks. Ou base sample includes 3998 banks from 10 countries over the period 2010-2019. Unconsolidated bank-level balance sheets and income statements are reported by Fitch Connect and winsorized at the $5 \%$ level. Country-level data are gathered profitability indicators (ROAA in regressions (1) and (5), NIM in regressions (2) and (6), PTP in regressions (3) and (7), and -CTI in regressions (4) and (8)), and four monetary policy measures (EURIBOR-1M and Spread:1OY-3M in regressions (1) to (4), and EURIBOR-6M and Spread:10Y- $6 M$ in regressions (5) to (8)). In both the credit risk and the profitability equations, all bank-level explanatory variables which are presumably endogenous in the existing literature are instrumented by their one-year lagged value. Time fixed effects are included in all regressions. $P$-values are computed using heteroskedasticity-robust standard errors clustered for banks, and $z$-statistics are reported in parentheses. ${ }^{*}$ are instrumented by their one-year lagged value. Time fixed effects are
$* *, * * *$ indicate significance at the $10 \%, 5 \%$ and $1 \%$ level, respectively.

rate.

The ROAA and PTP ratios are both significantly and negatively related to credit risk, while the opposite occurs for NIM and $-C T I$ (this result is also confirmed in the simultaneous profitability equation). Therefore, obtaining extra (interest) income implies taking more credit risk when monetary policy is eased; this result is a direct consequence of the risk-taking channel of monetary policy transmission (Neuenkirch and Nöckel, 2018). Moreover, the negative and significant signs of the Real GDP coefficients show that bank credit risk rises in economic downturns. Although the Size coefficients are contradictory depending on the profitability proxy used as the explanatory variable in the credit risk equation, a higher share of Net loans in a bank's assets seems to limit credit risk.

Focusing on the determinants of profitability, we observe a positively significant relationship between our interest rate proxies and profitability, confirming Borio et al. (2017)'s results on the positive link between short-term rates and bank profitability, which tends to erode as a low interest rate environment extends over time. Conversely, the increase in the spread between 10-year government bond yields and the euro interbank deposits rate is associated with better profitability. We also note the stronger dependence of -CTI on the monetary stance (with a significant coefficient of 0.664 for Spread:10Y-3M and
0.559 for Spread:10Y-6M) than the other profitability proxies. When significant, the level of capitalization (Equity) and business cycle (Real GDP) both improve bank profitability. A higher share of Liquid assets in total assets is achieved at the expense of lower bank profitability (see the negative coefficients, when significant).

\subsection{The effects of a low interest rate environment on credit risk and profitability: cooperative and non- cooperative banks}

We delve deeper into the influence of monetary policy on bank credit risk and profitability by separating cooperative banks from non-cooperative banks. The regression results are presented in Table 5 for cooperative banks and Table 6 for noncooperative banks.

First, we show that variations in ROAA do not significantly affect non-cooperative banks' credit risk ${ }^{12}$ as opposed to cooperative banks. This might be explained by the greater business diversification of non-cooperative banks resulting in a weaker relation between return on assets and credit risk. As cooperative banks are more involved in traditional financial intermediation ${ }^{13}$, they often access fewer diversification opportunities,

\footnotetext{
${ }^{12}$ However, the significance of the -0.029 ROAA coefficient in regression (1) from the credit risk equation in Table 6 is at the $12.8 \%$ level.

${ }^{13}$ See the significantly different means in net interest margins between
} 
Table 5: Cooperative banks' credit risk and profitability in a low interest rate environment (2010-2019).

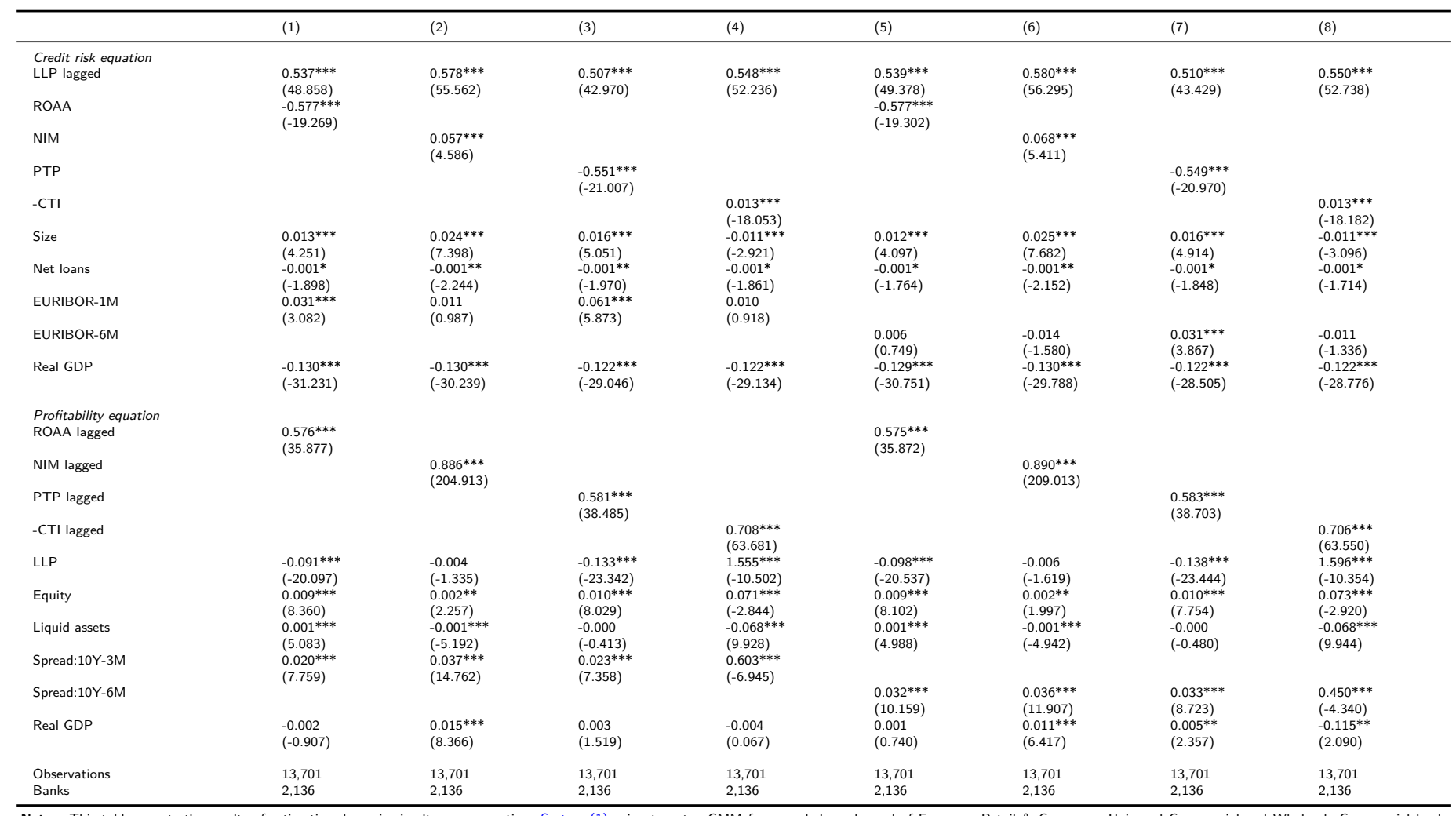

Notes: This table reports the results of estimating dynamic simultaneous equations System (1) using two-step GMM for an unbalanced panel of European Retail \& Consumer, Universal Commercial and Wholesale Commercial bank displaying a cooperative ownership structure. Our base sample includes 2136 banks from 10 countries over the period 2010-2019. Unconsolidated bank-level balance sheets and income statements are reported by Fitch Connect and one credit risk index (LLP in regressions (1) to (8)), four profitability indicators (ROAA in regressions (1) and (5). NIM in regressions (2) and (6), PTP in regressions (3) and (7), and -CTI in regressions (4) and (8)), and four monetary policy measures (EURIBOR-1M and Spread:10Y-3M in regressions (1) to (4), and EURIBOR-6M and Spread:10Y-6M in regressions (5) to (8)). In both the credit risk and the profitability equations, all bank-level explanatory variables

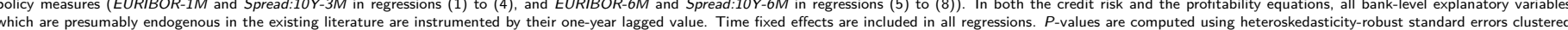
which are presumably endogenous in the existing literature are instrumented by their one-year lagged value. Time fixed effects are
for banks, and $z$-statistics are reported in parentheses. $*, * *, * * *$ indicate significance at the $10 \%, 5 \%$ and $1 \%$ level, respectively.

which exacerbates the link between return on assets and credit risk, as shown in regressions (1) and (5) in Table 5.

Second, the Size variable seems to affect credit risk differently depending on the ownership structure of banks. In particular, cooperative banks' size appears to be positively related to credit risk (except when the cost to income ratio gauges profitability in the credit risk equation; see regressions (4) and (8) in Table 5), which suggests that cooperative ownership and asset growth ultimately increase credit risk. By contrast, the regression results in Table 6 show the significantly negative relation between non-cooperative banks' size and credit risk. Accordingly, the greater non-cooperative banks' assets, the better is their credit risk management.

Third, the signs of the monetary policy coefficients in the credit risk equation conflict with one another when distinguishing between cooperative and non-cooperative banks. Confirming the results for the full sample presented in Table 4, noncooperative banks continue to display significantly negative EURIBOR-1M and EURIBOR-6M coefficients, consistent with the risk-taking channel in the 2010-2019 euro area banking industry previously identified. However, the non-significance of the EURIBOR-1M and EURIBOR-6M coefficients in regressions

cooperative and non-cooperative banks in Table 3.
(2), (4), (5), (6), and (8) from the credit risk equation in Table 5 supports, at least at the bank level, Caselli et al. (2020)'s insights into the capacity of bank ownership diversity to buffer the impact of exogenous monetary policy shocks on credit risk.

Fourth, the positive and significant EURIBOR-1M and EURIBOR-6M coefficients in regressions (1), (3), and (7) in Table 5 suggest that cooperative banks' credit risk decreases in a low interest rate environment compared with their noncooperative counterparts ${ }^{14}$. This result provides, at least partially, empirical confirmation of Hypothesis 1 , which claims that cooperative banks are less exposed to the risk-taking channel of monetary policy than non-cooperative banks thanks to the specificities of their business model. What matters now is to determine whether this result persists equally for consolidated and relationship-based cooperative banks.

Differentiating cooperative banks from non-cooperative banks does not alter the sign of the monetary policy indexes Spread:10Y-3M and Spread:10Y-6M in the profitability equation. However, greater significance levels in the interest rate coefficients of cooperative banks are noted, which confirms their higher sensitivity to monetary policy. Consequently, coopera-

\footnotetext{
${ }^{14}$ This is supported by the summary statistics in Table 3 , which show that cooperative banks' mean $L L P$ is significantly different (and in this case, lower) than that of non-cooperative banks.
} 
Table 6: Non-cooperative banks' credit risk and profitability in a low interest rate environment (2010-2019).

\begin{tabular}{|c|c|c|c|c|c|c|c|c|}
\hline & (1) & (2) & (3) & (4) & (5) & (6) & (7) & (8) \\
\hline \multicolumn{9}{|l|}{ Credit risk equation } \\
\hline LLP lagged & $0.546^{* * *}$ & $\begin{array}{l}0.541^{* * *} \\
(34.742)\end{array}$ & $\begin{array}{l}0.546^{* * *} \\
(34298)\end{array}$ & $0.538^{* * *}$ & $\begin{array}{l}0.545 * * * \\
(34669)\end{array}$ & $0.540^{* * *}$ & $\begin{array}{l}0.545^{* * *} \\
(34.346)\end{array}$ & $0.538 * * *$ \\
\hline ROAA & $\begin{array}{l}(34.621) \\
-0.029 \\
(-1.520)\end{array}$ & $(34.742)$ & (34.298) & $(34.661)$ & $\begin{array}{l}(34.669) \\
-0.030 \\
(-1.524)\end{array}$ & $(34.793)$ & $(34.346)$ & $(34.701)$ \\
\hline NIM & & $\begin{array}{l}0.041^{* * *} \\
(3.612)\end{array}$ & & & & $\begin{array}{l}0.042^{* * *} \\
(3.663)\end{array}$ & & \\
\hline PTP & & & $\begin{array}{l}-0.047 * * * \\
(-2.899)\end{array}$ & & & & $\begin{array}{l}-0.047 * * * \\
(-2.899)\end{array}$ & \\
\hline$-\mathrm{CTI}$ & & & & $\begin{array}{l}0.004 * * * \\
(-7.514)\end{array}$ & & & & $\begin{array}{l}0.004 * * * \\
(-7.531)\end{array}$ \\
\hline Size & $\begin{array}{l}-0.021 * * * \\
(-4.370)\end{array}$ & $\begin{array}{l}-0.015 * * * \\
(-2.888)\end{array}$ & $\begin{array}{l}-0.023 * * * \\
(-4.654)\end{array}$ & $\begin{array}{l}-0.029^{* * *} \\
(-5.682)\end{array}$ & $\begin{array}{l}-0.022 * * * \\
(-4.378)\end{array}$ & $\begin{array}{l}-0.015 * * * \\
(-2.884)\end{array}$ & $\begin{array}{l}-0.023 * * * \\
(-4.661)\end{array}$ & $\begin{array}{l}-0.029^{* * *} \\
(-5.693)\end{array}$ \\
\hline Net loans & $\begin{array}{l}-0.001 * * * \\
(-2.893)\end{array}$ & $\begin{array}{l}-0.002 * * * \\
(-4.404)\end{array}$ & $\begin{array}{l}-0.001 * * * \\
(-2.914)\end{array}$ & $\begin{array}{l}-0.002 * * * \\
(-3.852)\end{array}$ & $\begin{array}{l}-0.001 * * * \\
(-2.908)\end{array}$ & $\begin{array}{l}-0.002 * * * \\
(-4.440)\end{array}$ & $\begin{array}{l}-0.001 * * * \\
(-2.929)\end{array}$ & $\begin{array}{l}-0.002^{* * *} \\
(-3.870)\end{array}$ \\
\hline EURIBOR-1M & $\begin{array}{l}-0.066 * * * \\
(-5.231)\end{array}$ & $\begin{array}{l}-0.073 * * * \\
(-5.531)\end{array}$ & $\begin{array}{l}-0.067 * * * \\
(-5.293)\end{array}$ & $\begin{array}{l}-0.077 * * * \\
(-5.879)\end{array}$ & & & & \\
\hline EURIBOR-6M & & & & & $\begin{array}{l}-0.054^{* * *} \\
(-5.659)\end{array}$ & $\begin{array}{l}-0.061 * * * \\
(-6.006)\end{array}$ & $\begin{array}{l}-0.055 * * * \\
(-5.724)\end{array}$ & $\begin{array}{l}-0.063 * * * \\
(-6.341)\end{array}$ \\
\hline Real GDP & $\begin{array}{l}-0.139 * * * \\
(-24.600)\end{array}$ & $\begin{array}{l}-0.140 * * * \\
(-24.515)\end{array}$ & $\begin{array}{l}-0.138^{* * *} \\
(-24.633)\end{array}$ & $\begin{array}{l}-0.140 * * * \\
(-24.444)\end{array}$ & $\begin{array}{l}-0.140 * * * \\
(-24.625)\end{array}$ & $\begin{array}{l}-0.142^{* * *} \\
(-24.606)\end{array}$ & $\begin{array}{l}-0.139^{* * *} \\
(-24.657)\end{array}$ & $\begin{array}{l}-0.141 * * * \\
(-24.546)\end{array}$ \\
\hline \multicolumn{9}{|l|}{ Profitability equation } \\
\hline ROAA lagged & $\begin{array}{l}0.723 * * * \\
(50.992)\end{array}$ & & & & $\begin{array}{l}0.723^{* * *} \\
(50.997)\end{array}$ & & & \\
\hline NIM lagged & & $\begin{array}{l}0.898 * * * \\
(136.651)\end{array}$ & & & & $\begin{array}{l}0.898^{* * *} \\
(136.970)\end{array}$ & & \\
\hline PTP lagged & & & $\begin{array}{l}0.740 * * * \\
(55.019)\end{array}$ & & & & $\begin{array}{l}0.740 * * * \\
(55.039)\end{array}$ & \\
\hline -CTI lagged & & & & $\begin{array}{l}0.798 * * * \\
(80.259)\end{array}$ & & & & $\begin{array}{l}0.799 * * * \\
(80.407)\end{array}$ \\
\hline LLP & $\begin{array}{l}-0.027 * * * \\
(-4.262)\end{array}$ & $\begin{array}{l}0.025 * * * \\
(4.526)\end{array}$ & $\begin{array}{l}-0.044 * * * \\
(-5.633)\end{array}$ & $\begin{array}{l}0.515 * * * \\
(-3.847)\end{array}$ & $\begin{array}{l}-0.028^{* * *} \\
(-4.306)\end{array}$ & $\begin{array}{l}0.026 * * * \\
(4.641)\end{array}$ & $\begin{array}{l}-0.045 * * * \\
(-5676)\end{array}$ & $\begin{array}{l}0.534 * * * \\
(-3970)\end{array}$ \\
\hline Equity & $0.007 * * *$ & -0.000 & $0.008^{* * *}$ & -0.024 & $0.007 * * *$ & -0.000 & $0.008 * * *$ & $-0.025^{*}$ \\
\hline & $(8.508)$ & $(-0.116)$ & $(8.104)$ & $(1.564)$ & $(8.532)$ & $(-0.210)$ & $(8.122)$ & $(1.675)$ \\
\hline Liquid assets & $\begin{array}{l}-0.000 \\
(-0.785)\end{array}$ & $\begin{array}{l}-0.001 * * * \\
(-3630)\end{array}$ & $\begin{array}{l}-0.001^{*} \\
(-1868)\end{array}$ & $-0.030 * * *$ & $\begin{array}{l}-0.000 \\
(-0.783)\end{array}$ & $\begin{array}{l}-0.001 * * * \\
(-3.545)\end{array}$ & $\begin{array}{l}-0.001^{*} \\
(-1869)\end{array}$ & $\begin{array}{l}-0.029 * * * \\
(4.068)\end{array}$ \\
\hline Spread:10Y-3M & $\begin{array}{l}0.005 \\
(1.129)\end{array}$ & $\begin{array}{l}0.017 * * * \\
(4.797)\end{array}$ & $\begin{array}{l}0.007 \\
(1.210)\end{array}$ & $\begin{array}{l}0.522^{* * * *} \\
(-5.158)\end{array}$ & & & & \\
\hline Spread:10Y-6M & & & & & $\begin{array}{l}0.007 \\
(1.446)\end{array}$ & $\begin{array}{l}0.015 * * * \\
(3.728)\end{array}$ & $\begin{array}{l}0.010 \\
(1.577)\end{array}$ & $\begin{array}{l}0.452^{* * *} \\
(-4.003)\end{array}$ \\
\hline Real GDP & $\begin{array}{l}0.010^{* * *} \\
(3.348)\end{array}$ & $\begin{array}{l}0.018^{* * *} \\
(6.259)\end{array}$ & $\begin{array}{l}0.013^{* * *} \\
(3.613)\end{array}$ & $\begin{array}{l}0.177^{* *} \\
(-2.248)\end{array}$ & $\begin{array}{l}0.011 * * * \\
(3.642)\end{array}$ & $\begin{array}{l}0.016 * * * \\
(5.736)\end{array}$ & $\begin{array}{l}0.014 * * * \\
(3.922)\end{array}$ & $\begin{array}{l}0.137^{*} \\
(-1.715)\end{array}$ \\
\hline Observations & 12,445 & 12,445 & 12,445 & 12,445 & 12,445 & 12,445 & 12,445 & 12,445 \\
\hline Banks & 1,862 & 1,862 & 1,862 & 1,862 & 1,862 & 1,862 & 1,862 & 1,862 \\
\hline
\end{tabular}

Notes: This table reports the results of estimating dynamic simultaneous equations System (1) using two-step GMM for an unbalanced panel of European Retail \& Consumer, Universal Commercial and Wholesale Commercial banks displaying a non-cooperative ownership structure. Our base sample includes 1862 banks from 10 countries over the period 2010-2019. Unconsolidated bank-level balance sheets and income statements are reported by Fitch Connect and one credit risk index (LLP in regressions (1) to (8)), four profitability indicators (ROAA in regressions (1) and (5). NIM in regressions (2) and (6), PTP in regressions (3) and (7), and -CTI in regressions (4) and (8)), and four monetary policy measures (EURIBOR-1M and Spread:10Y-3M in regressions (1) to (4), and EURIBOR-6M and Spread:10Y-6M in regressions (5) to (8)). In both the credit risk and the profitability equations, all bank-level explanatory variables

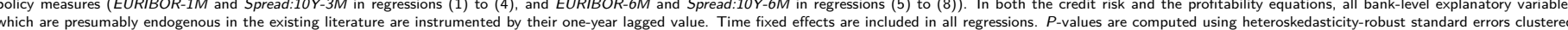
which are presumably endogenous in the existing literature are instrumented by their one-year lagged value. Time fixed effects are
for banks, and $z$-statistics are reported in parentheses. ${ }^{*}, * *, * * *$ indicate significance at the $10 \%, 5 \%$ and $1 \%$ level, respectively.

tive banks' profitability might be relatively more exposed when interest rates remain at historical lows for a long time.

\subsection{The effects of a low interest rate environment on credit risk and profitability: consolidated and relationship-based cooperative banks}

We now examine in detail the credit risk and profitability of cooperative banks that, despite the pressure exerted by low interest rates on their balance sheets, preserve a relationshipbased network of local branches to maintain their commitment to relationship lending (McKillop et al., 2020). The regression results are presented in Table 7 for consolidated cooperative banks and Table 8 for relationship-based cooperative banks.

First, the differences in the Size coefficient signs between consolidated cooperative and relationship-based cooperative banks suggest that a cooperative bank increasing its business volume - in terms of assets-while remaining committed to relationship lending is more prone to credit risk (as suggested by the significantly positive Size coefficients in Table 8). By contrast, the greater the size of consolidated cooperative banks' assets, the better is their credit risk management (as suggested by the significantly negative Size coefficients in Table 7).

Second, the dependence of credit risk on the volume of net loans appears to be lower for relationship-based cooperative banks, as shown by the differences in the significance level of the Net loans variables from one group to another. When consolidated, cooperative banks granting more loans perform better in terms of credit risk, which could mean that a positive volume effect is operating ${ }^{15}$.

Third, unlike previous results, the credit risk of consolidated cooperative banks is positively correlated with the business cycle variable, Real GDP (see Table 7) in stark contrast to relationship-based cooperative banks that show countercyclical credit risk (see the significantly negative Real GDP coefficients in Table 8). However, such a finding is in line with Beck et al. (2018) emphasizing that a greater presence of relationship banks is associated with fewer credit constraints during cyclical downturns. Conversely, this easing effect mainly benefits safe firms in times of economic booms and is positively associated with firm investment and growth. As a result, relationship banks can smooth the negative impact of cyclical downturns after having acquired sufficient information on borrowers during good times.

Fourth, the Spread:10Y-3M and Spread:10Y-6M variables in the profitability equation display higher significance levels in

\footnotetext{
${ }^{15}$ On average, consolidated cooperative banks display a significantly higher net loans to assets ratio than non-consolidated cooperative banks over the full sample period (see Table 3 ).
} 
Table 7: Consolidated cooperative banks' credit risk and profitability in a low interest rate environment (2010-2019).

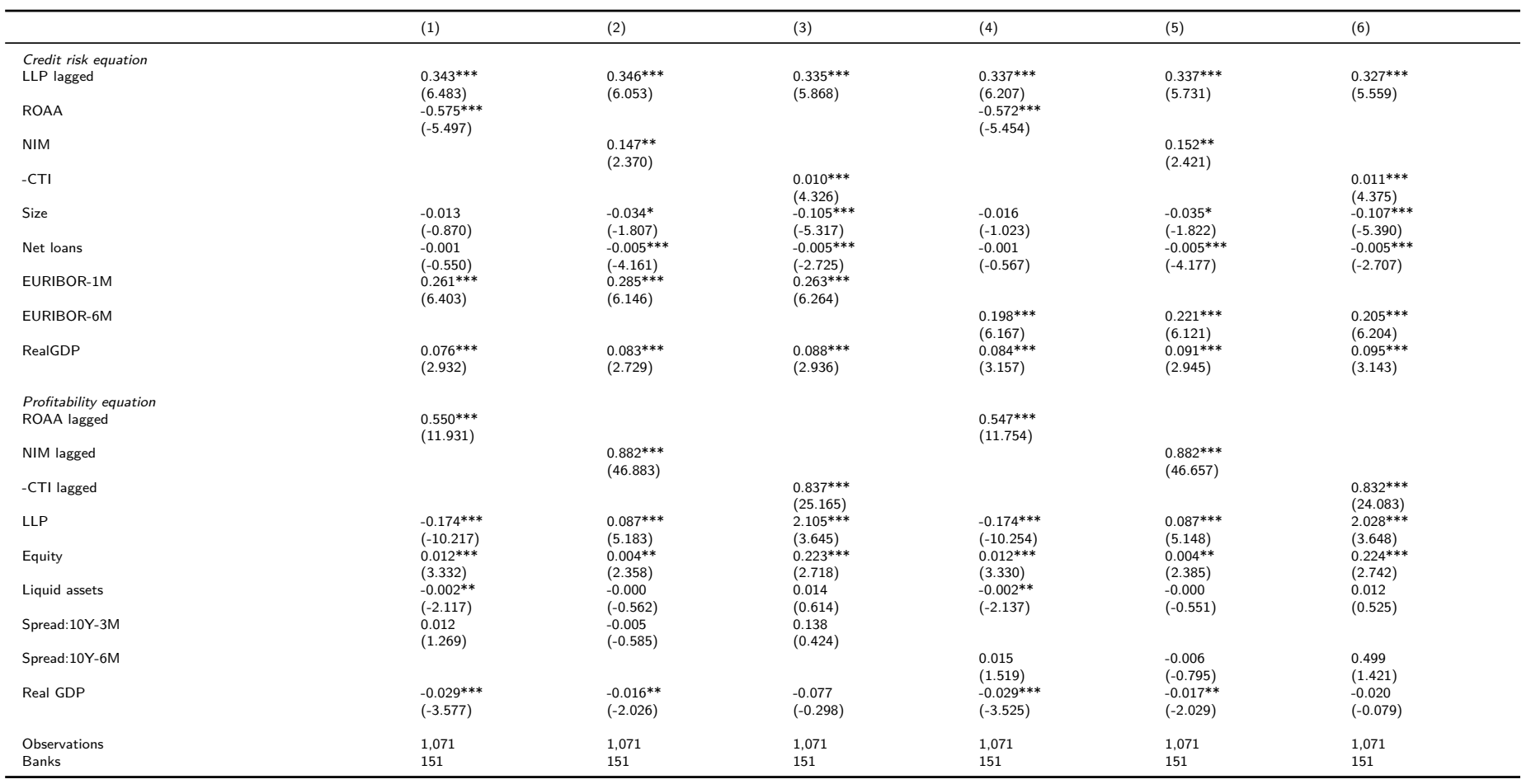

Notes: This table reports the results of estimating dynamic simultaneous equations System (1) using two-step GMM for an unbalanced panel of European Retail \& Consumer, Universal Commercial and Wholesale Commercial banks displaying a cooperative ownership structure with a number of clients per branch above the full sample median in 2019 (see Table A2 and EACB (2020a)). Our base sample includes 151 banks from 5 countries over the period 2010-2019. Unconsolidated bank-level balance sheets and income statements are reported by Fitch Connect and winsorized at the $5 \%$ level. Country-level data are gathered from Eurostat and Thompson Reuters Eikon. See Table 1 for the definition of all explanatory variables, and Table 2 for descriptive statistics and correlations. Estimations include one credit risk index (LLP in regressions (1) to (6)), three profitability indicators (ROAA in regressions (1) and (4), NIM in regressions (2) and (5), and -CTI in regressions (3) and (6)), and four monetary policy measures (EURIBOR-1M and Spread:10Y-3M in regressions (1) to (3), and EURIBOR-6M and Spread:10Y-6M in regressions (4) to (6)). In both the credit risk and the profitability equations, all bank-level explanatory variables which are presumably endogenous in the existing literature are instrumented by their one-year lagged value. Time fixed effects are included in all regressions. $P$-values are
computed using heteroskedasticity-robust standard errors clustered for banks, and $z$-statistics are reported in parentheses. **,**,*** indicate significance at the $10 \%, 5 \%$ and $1 \%$ level, respectively.

the relationship-based cooperative banks subsample. Accordingly, cooperative banks committed to relationship lending are concerned by higher profitability dependence on monetary policy in a low interest rate environment. This result confirms, for relationship-based cooperative banks, Borio et al. (2017)'s evidence of the link between short-term rates and the slope of the yield curve; this effect is even stronger when the slope is steeper and bank size smaller (Genay, 2014). Therefore, we provide empirical support to Hypothesis 2, which proposed that the profitability of cooperative banks preserving their relationship lending model is more severely hit by a low interest rate environment than that of cooperative banks opting for consolidation. In addition, relationship lending may be associated with different governance structures in which profitability may not be the only mission to be fulfilled.

Finally, consolidated cooperative banks display a great capacity to buffer the impact of exogenous monetary policy shocks on credit risk. This interpretation is led by the highly significant and positive EURIBOR-1M and EURIBOR-6M coefficients in Table $7^{16}$. However, the ability of relationship-based cooperative banks to reduce their exposure to the risk-taking channel of monetary policy when interest rates are low differs in reality. When significant, the EURIBOR-1M and EURIBOR-6M

\footnotetext{
${ }^{16}$ Such an ability is even stronger for consolidated cooperative banks than cooperative banks more broadly (compare with the coefficients in Table 5).
}

coefficients turn negative, as shown in regressions (3), (5), and (6) in Table 8. Unlike consolidated cooperative banks, cooperative banks committed to relationship lending actually increase their willingness to raise credit risk in a low interest rate environment. Hence, we confirm Hypothesis 3 that proposed that cooperative banks preserving their relationship lending model in a low interest rate environment are prone to assume greater credit risk than cooperative banks opting for consolidation.

Although this result is similar to the estimations for noncooperative banks (see Table 6), we posit that such a similarity is not explained by the same reasons, mainly because noncooperative banks and relationship-based cooperative banks organize their business models and engage with customers in a different way. This important difference is consistent with the contribution of Jiménez and Saurina (2004) on the role of the bank-customer relationship in credit risk as well as supports Peltoniemi (2007)'s view on (long-term) bank-firm relationships being beneficial to high-risk firms.

In the aftermath of the global financial crisis, Anderson and Stallings (2013) identify in the European banking industry that information about SME creditworthiness and potential is often considered costly and difficult to obtain (as a consequence of banks' disinvestments in front-end staff who interface directly with borrowers), which might deter SMEs to achieve greater scale to be competitive and financially healthy, leading alternative funding providers to stray away from financing them. Along 
Table 8: Relationship-based cooperative banks' credit risk and profitability in a low interest rate environment (2010-2019).

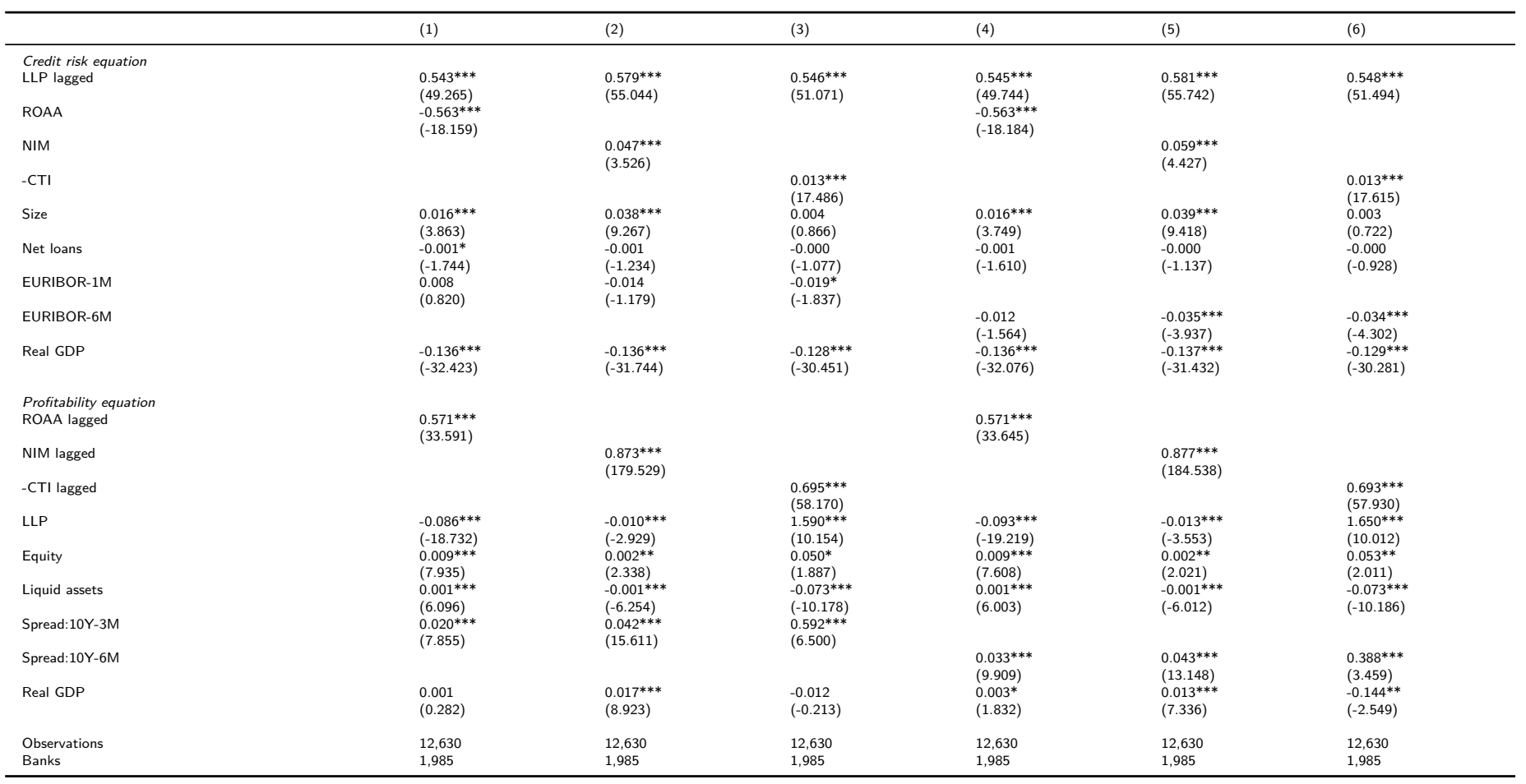

Notes: This table reports the results of estimating dynamic simultaneous equations System (1) using two-step GMM for an unbalanced panel of European Retail \& Consumer, Universal Commercial and Wholesale Commercial banks displaying a cooperative ownership structure with a number of clients per branch below the full sample median in 2019 (see Table A2 and EACB (2020a)). Our base sample includes 1985 banks from 7 countries over the period 2010-2019. Unconsolidated bank-level balance sheets and income statements are reported by Fitch Connect and winsorized at the $5 \%$ level. Country-level data are gathered from Eurostat and Thompson Reuters Eikon. See Table 1 for the definition of all explanatory variables, and Table 2 for descriptive statistics and correlations. Estimations include one credit risk index (LLP in regressions (1) to (6)), three profitability indicators (ROAA in regressions (1) and (4), NIM in regressions (2) and (5), and -CTI in regressions (3) and (6)), and four monetary policy measures (EURIBOR-1M and Spread:1OY-3M in regressions (1) to (3), and EURIBOR-6M and Spread:10Y-6M in regressions (4) to (6)). In both the credit risk and the profitability equations, all bank-level explanatory variables which are presumably endogenous in the existing literature are instrumented by their one-year lagged value. Time fixed effects are in
computed using heteroskedasticity-robust standard errors clustered for banks, and $z$-statistics are reported in parentheses. ${ }^{*},{ }^{* *},{ }^{* * *}$ indicate significance at the $10 \%, 5 \%$ and $1 \%$ level, respectively.

the same lines, Beck et al. (2018) highlight that the presence of relationship banks is beneficial in particular for smaller, younger, and more opaque firms with less collateral to pledge as SME financing requires a subtler judgment of the ability and commitment of firm owners to make informed loan decisions.

Analyzing the effect of relationship lending on firm activity in Italy following Lehman Brothers' default shock, Banerjee et al. (2017) argue that banks offer more favourable continuation lending terms to firms with which they had stronger relationships; these tighter bank-firm relationships being still present during the European sovereign debt crisis, especially for firms tied to well capitalised banks. Moreover, López-Espinosa et al. (2017) suggest that SMEs generate much less public information, have lower quality financial statements, and are often not audited nor studied by professional analysts. In this sense, the bank-firm information generated throughout the lending relationship may be especially valuable for banks when setting interest rates in loan contracts.

More recently, Hasan et al. (2020) examine lending banks' and borrowing firms' exposure to COVID-19 pandemic to evidence that the formation of strong bank-firm relationships helps reduce the upward pressure on loan spreads stemming from the bank's exposure, while such spread may prove crucial for SMEs weakened by the health crisis. Therefore, empirical evidence supports the interpretation of our results regarding relationshipbased cooperative banks.

\subsection{Robustness checks}

To further address the assumption that interest rate changes are exogenous to credit risk (i.e., that monetary policy does not respond to the riskiness of newly issued loans), we undertake additional robustness checks. Table 9 presents the results.

First, endogeneity is likely to be more of a concern for nationwide banks whose loan portfolios reflect economic activity across the country than it is for small, local banks primarily affected by local shocks (Dell'Ariccia et al., 2017). Therefore, we re-estimate System (1) excluding large banks from the sample 17 for which endogeneity is more of a concern. Columns (1) and (2) in Table 9 report the results. We find similarly significant coefficients to our preliminary results in Table 4. In particular, the negative coefficients of the EURIBOR-1M and EURIBOR$6 M$ variables and positive coefficients of Spread:10Y-3M and Spread:10Y-6M are similar to those obtained in the full sample. This suggests that our results are not contaminated by the inclusion of large banks.

Moreover, our results might also be driven by the business cycle, as credit risk might adjust endogenously with the state of the economy. We thus control for direct changes in the economic activity in regressions (3) and (4) by including a $R e-$ cession dummy ${ }^{18}$ and its interaction with the monetary policy

\footnotetext{
${ }^{17}$ That is, banks with assets in the top quartile of the full sample.

${ }^{18}$ The dummy variable equals 1 when the Real GDP variable is negative
} 
Table 9: Credit risk and profitability in a low interest rate environment (2010-2019): robustness checks.

\begin{tabular}{|c|c|c|c|c|c|c|c|c|}
\hline & \multicolumn{2}{|c|}{ Without large banks } & \multicolumn{2}{|c|}{ Impact of business cycles } & \multicolumn{4}{|c|}{-Zscore as dependent variable } \\
\hline & (1) & (2) & (3) & (4) & (5) & (6) & (7) & (8) \\
\hline $\begin{array}{l}\text { Credit risk and overall risk equations } \\
\text { LLP lagged }\end{array}$ & $0.546 * * *$ & $0.5477^{* * *}$ & $0.559 * * *$ & $0.552^{* * *}$ & & & & \\
\hline -Zscore lagged & & & & & $\begin{array}{l}1.001 * * * \\
(1678.206)\end{array}$ & $\begin{array}{l}1.001 * * * \\
(1678.664)\end{array}$ & $\begin{array}{l}1.001 * * * \\
(1654.162)\end{array}$ & $\begin{array}{l}1.001^{* * *} \\
(1653.980)\end{array}$ \\
\hline ROAA & $\begin{array}{l}-0.171 * * * \\
(-8.076)\end{array}$ & & & & & & & \\
\hline NIM & & $\begin{array}{l}0.024 * * \\
(2.088)\end{array}$ & & & $\begin{array}{l}-0.014 * * * \\
(-6.227)\end{array}$ & $\begin{array}{l}-0.013 * * * \\
(-6.034)\end{array}$ & & \\
\hline PTP & & & $\begin{array}{l}-0.154 * * * \\
(-10.296)\end{array}$ & & & & & \\
\hline- CTI & & & & $0.007 * * *$ & & & $-0.001 * *$ & $-0.001 * * *$ \\
\hline Size & $\begin{array}{l}-0.008 \\
(-1.471)\end{array}$ & $\begin{array}{l}0.004 \\
(0.810)\end{array}$ & $\begin{array}{l}-0.005^{*} \\
(-1.957)\end{array}$ & $\begin{array}{l}-0.013 * * * \\
(-4.825)\end{array}$ & $\begin{array}{l}-0.005 * * * \\
(-8.146)\end{array}$ & $\begin{array}{l}-0.005 * * * \\
(-8.059)\end{array}$ & $\begin{array}{l}-0.002^{* * *} \\
(-2.708)\end{array}$ & $\begin{array}{l}-0.002^{* * *} \\
(-2.733)\end{array}$ \\
\hline $\begin{array}{l}\text { Net loans } \\
\text { EURIBOR-1M }\end{array}$ & $\begin{array}{l}(-1.471) * 0 \\
-0.002 * * \\
(-4.976)\end{array}$ & 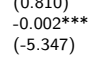 & $\begin{array}{l}(-1.95) 7 * \\
-0.001 * * \\
(-2.989) \\
-0.068 * * *\end{array}$ & $\begin{array}{l}-(-4.8018) * \\
-0.01 * * \\
(-4.155)\end{array}$ & $\begin{array}{l}(-8.1 .160) \\
0.00 * * \\
(5.572) \\
-0.018^{* * *}\end{array}$ & $\begin{array}{l}(-8.0059) * \\
0.000 * * \\
(5.500)\end{array}$ & $\begin{array}{l}(-2.7 .70) * \\
0.00 * * * \\
(4.390) \\
-0.020 * * *\end{array}$ & $\begin{array}{l}-(-2.7 .73) * \\
0.00 * * * \\
(4.382)\end{array}$ \\
\hline EURIBOR-6M & $-0.024 * * *$ & $-0.028 * * *$ & $(-7.737)$ & $-0.073^{* * *}$ & $(-8.082)$ & $-0.016 * * *$ & $(-9.556)$ & $-0.017 * * *$ \\
\hline RealGDP & $\begin{array}{l}(-3.151) \\
-0.134^{* * *}\end{array}$ & $\begin{array}{l}(-3.268) \\
-0.135 * * *\end{array}$ & & $(-10.765)$ & $-0.008^{* * *}$ & $\begin{array}{l}(-9.137) \\
-0.008^{* * *}\end{array}$ & $-0.008^{* * *}$ & $\begin{array}{l}-1-008^{* * *} \\
-0.04\end{array}$ \\
\hline Recession & $(-31.683)$ & $(-31.428)$ & $0.695 * * *$ & $0.660^{* * *}$ & $(-10.346)$ & $(-10.762)$ & $(-10.865)$ & \\
\hline EURIBOR-1M * Recession & & & $\begin{array}{l}(26.604) \\
-0.247 * *\end{array}$ & $(18.458)$ & & & & \\
\hline EURIBOR-6M * Recession & & & & $\begin{array}{l}-0.044 \\
(-1.018)\end{array}$ & & & & \\
\hline $\begin{array}{l}\text { Profitability equation } \\
\text { ROAA lagged }\end{array}$ & $0.690 * * *$ & & & & & & & \\
\hline NIM lagged & (50.137) & $0.882^{* * *}$ & & & $0.897 * * *$ & $0.898 * * *$ & & \\
\hline PTP lagged & & $(136.040)$ & $\begin{array}{l}0.710^{* * *} \\
(61.796)\end{array}$ & & $(197.190)$ & (198.663) & & \\
\hline -CTI lagged & & & & $0.771 * * *$ & & & $0.774 * * *$ & $0.773^{* * *}$ \\
\hline LLP & $-0.058^{* * *}$ & 0.004 & $-0.078 * * *$ & $\begin{array}{l}(100.1022) \\
0.887^{* * *}\end{array}$ & & & (102.889) & (102.357) \\
\hline -Zscore & $(-11.710)$ & $(0.989)$ & $(-14.712)$ & $(-8.865)$ & -0.001 & -0.001 & -0.039 & -0.039 \\
\hline Equity & $0.008 * * *$ & -0.001 & $0.009 * * *$ & -0.015 & & & & (1.602) \\
\hline Liquid assets & $\begin{array}{l}(9.111) \\
0.000\end{array}$ & $\begin{array}{l}(-1.010) \\
-0.001 * * \\
x^{*}\end{array}$ & $\begin{array}{l}(10.163) \\
-0.000\end{array}$ & $\begin{array}{l}(1.068) \\
-0.041^{* *}\end{array}$ & $-0.001 * * *$ & $-0.001 * * *$ & $-0.046 * * *$ & $-0.046 * * *$ \\
\hline Spread:10Y-3M & $(0.774)$ & $(-4.553)$ & $\begin{array}{l}(-1.286) \\
0.026 * * *\end{array}$ & $(7.496)$ & $\begin{array}{l}(-4.854) \\
0.030^{* * *}\end{array}$ & $(-4.659)$ & $\begin{array}{l}(8.555) \\
0.910^{* * *}\end{array}$ & $(8.435)$ \\
\hline Spread:10Y-6M & $0.019^{* * *}$ & $0.034^{* * *}$ & $(7.046)$ & $0.337 * * *$ & $(14.763)$ & $0.028^{* * *}$ & $(-13.770)$ & $0.891^{* * *}$ \\
\hline Real GDP & $\begin{array}{l}(4.472) \\
0.003\end{array}$ & $\begin{array}{l}(9.965) \\
0.013^{* * *}\end{array}$ & & $(-4.010)$ & $0.015^{* * *}$ & $\begin{array}{l}(12.209) \\
0.012^{* * *}\end{array}$ & 0.018 & $\begin{array}{l}(-11.497) \\
-0.045\end{array}$ \\
\hline Recession & $(1.357)$ & $(6.942)$ & & $4.351 * * *$ & $(9.234)$ & $(7.623)$ & $(-0.373)$ & \\
\hline Spread:10Y-3M * Recession & & & $\begin{array}{l}(2.605) \\
-0.054 * * *\end{array}$ & $(-4.217)$ & & & & \\
\hline Spread:10Y-6M * Recession & & & $(-4.408)$ & $\begin{array}{l}-0.647 * * \\
(2.179)\end{array}$ & & & & \\
\hline Observations & $\begin{array}{l}19,432 \\
3,966\end{array}$ & $\begin{array}{l}19,432 \\
3,196\end{array}$ & $\begin{array}{l}26,146 \\
309\end{array}$ & $\begin{array}{l}26,146 \\
3008\end{array}$ & $\begin{array}{l}25,983 \\
3941\end{array}$ & 25,983 & $\begin{array}{c}25,983 \\
3941\end{array}$ & $\begin{array}{l}25,983 \\
304\end{array}$ \\
\hline
\end{tabular}

proxies (in both the credit risk and the profitability equations). Again, we continue to obtain the same significant signs on the link between monetary policy and both bank credit risk and profitability.

We rerun our estimations using another indicator of bank risk commonly used in the literature (Ramayandi et al., 2014), namely, the Z-score (see Table 1 and Equation 2 for the methodological approach to build the index). As stressed by Khan et al. (2017), model specifications using the Z-score as the dependent variable should not include ROAA or Equity as controls because the Z-score index is a function of these two indicators. As such, there is a significant risk of obtaining misleading results. Therefore, regressions (5) to (8) do not use the ROAA variable in the overall risk equation or the Equity variable in the profitability equation. In addition, as noted earlier, because reductions in the Z-score imply higher bank risk, whereas increases in $L L P$ convert to higher credit risk, we multiply the values of banks' Z-scores by -1 to facilitate a more consistent interpretation. Once again, our results on the influence of interest rate variations on credit risk and profitability remain unchanged.

Together with the fixed effects and GMM estimation techniques, those robustness checks confirm that our main results hold, alleviating any concerns that the empirical analysis is contaminated by an endogenous response of monetary policy to bank credit risk. 


\section{Conclusion}

This study analyzes the effects of monetary easing on bank credit risk and profitability in 10 euro area countries between 2010 and 2019. Specifically, we investigate how such effects depend on bank ownership structures and, for cooperative banks, how they interact with relationship lending practices. Building on previous studies indicating that credit risk and profitability are jointly determined, we consider a simultaneous equations system to examine how relationship lending implemented by cooperative banks influences their performance in a low interest rate environment.

The main results are threefold. First, we find no evidence of the presence of a risk-taking channel of monetary policy for consolidated cooperative banks, whereas such a channel is extensively shown in the euro area for non-cooperative banks. Therefore, consolidated cooperative banks do not seem to raise their credit risk significantly when monetary policy is eased, distinguishing them from non-cooperative banking institutions. Second, we highlight that the profitability of cooperative banks preserving their relationship lending model is more severely hit by a low interest rate environment than that of cooperative banks opting for consolidation. This raises issues about the middle-term durability of relationship lending given the longstanding low interest rates in the European banking industry. This result may also be due to the fact that relationship lending is associated with governance structures in which profitability is not the only strategic objective to be met. Third, we find that non-cooperative banks and relationship-based cooperative banks are both concerned by the risk-taking channel of monetary policy transmission, which increases their credit risk under accommodating monetary policy conditions. Nevertheless, we suggest that such similarities do not occur for the same reasons because relationship lending is associated with a fundamentally different lending process than transactions-based lending technologies that devote significantly lower proportions of their assets to lending to small businesses (Berger and Udell, 2002).

Under "low-for-long" interest rates, non-cooperative banks prioritize maintaining their profitability at the expense of higher credit risk (Kuc and Teply, 2019), whereas relationship-based cooperative banks increase their capital buffers (on average, the capitalization of relationship-based cooperative banks is significantly higher than that of consolidated cooperative banks) to ensure access to credit, including for risky local businesses. As a close bank-customer relationship produces informational rents for the cooperative banks involved, such banks exercise some degree of market power and are better prepared to finance riskier borrowers and projects. While one might be concerned about the durability of relationship lending when interest rates are close to the zero lower bound, this insight points to the crucial impact of the bank-customer relationship on the development of regional and local economies. Accordingly, the greater the relationship lending strategy of a cooperative bank, the greater is its willingness to undertake credit risk, which is particularly valuable to high-risk firms and small businesses, as they are often informationally opaque and have far fewer external finance alternatives than large companies.

The conclusions presented in this paper suggest that further research on the impact of the risk-taking channel of monetary policy on relationship-based cooperative banks may yield new insights into alternative transmission mechanisms to the traditional channels already identified in the literature on commercial (i.e., non-cooperative) banking. Specifically, comparing customer risk profiles with the duration of relationship lending in a low interest rate environment is a promising path toward better understanding the "local virtues" driven by cooperative banks committed to relationship lending. 
Table A1: European cooperative banking: trends in the total number of clients per branch (2010-2019).

\begin{tabular}{|c|c|c|c|c|c|c|c|c|c|c|c|}
\hline & 2010 & 2011 & 2012 & 2013 & 2014 & 2015 & 2016 & 2017 & 2018 & 2019 & $\begin{array}{l}2010-2019 \\
\% \text { change }\end{array}$ \\
\hline \multicolumn{12}{|l|}{ Austria } \\
\hline Österreichische Raiffeisenbanken & 2,071 & 2,142 & 2,050 & 2,187 & 2,268 & 2,281 & 2,400 & 2,486 & 2,497 & 2,246 & $+8.45 \%$ \\
\hline Österreichischer Volksbanken & 1,468 & n.a. & 1,714 & 1,758 & 2,345 & 2,284 & 2,935 & 3,307 & 3,649 & 4,017 & $+173.64 \%$ \\
\hline \multicolumn{12}{|l|}{ Finland } \\
\hline OP Financial Group & 7,460 & 7,781 & 8,112 & 9,304 & 9,395 & 9,562 & 9,857 & 10,811 & 11,732 & 11,063 & $+48.30 \%$ \\
\hline \multicolumn{12}{|l|}{ France } \\
\hline Crédit Agricole & n.a. & 4,655 & 3,000 & 5,385 & 5,514 & 4,505 & 4,727 & 5,977 & 6,000 & 6,190 & $+32.98 \% a$ \\
\hline Crédit Mutuel & 5,000 & n.a. & 3,280 & 5,135 & 5,681 & 5,837 & 5,851 & 6,124 & 6,354 & 6,840 & $+36.80 \%$ \\
\hline BPCE & n.a. & n.a. & n.a. & 4,781 & 4,500 & 4,375 & 3,900 & 4,000 & 4,032 & 4,032 & $-15.67 \%^{c}$ \\
\hline \multicolumn{12}{|l|}{ Germany } \\
\hline $\begin{array}{l}\text { Cooperative Financial Network - Bundesverband der } \\
\text { Deutschen Volksbanken und Raiffeeisenbanken (Volks- } \\
\text { banks, Raiffeisenbanks, Sparda-banks, PSD banks, and } \\
\text { DZ banks) }\end{array}$ & 2,227 & 2,247 & 2,270 & 2,298 & 2,349 & 2,529 & 2,545 & 2,701 & 2,852 & 3,211 & $+44.19 \%$ \\
\hline \multicolumn{12}{|l|}{ Italy } \\
\hline $\begin{array}{l}\text { Cooperative Financial Network (Raiffeisen, Banco Popo- } \\
\text { lare, and Credito Cooperativo) }\end{array}$ & 1,302 & 1,360 & n.a. & 1,347 & 1,351 & 1,359 & 1,392 & 1,410 & 1,417 & 1,417 & $+8.83 \%$ \\
\hline \multicolumn{12}{|l|}{ Luxembourg } \\
\hline Banque Raiffeissen & 2,594 & 2,297 & 2,649 & 2,174 & 2,330 & 2,732 & 2,732 & 3,126 & 3,179 & 3,225 & $+24.33 \%$ \\
\hline \multicolumn{12}{|l|}{ The Netherlands } \\
\hline Rabobank & 8,306 & 11,467 & 8,959 & 13,850 & 16,088 & 16,996 & 20,471 & 19,144 & 20,293 & 25,606 & $+208.28 \%$ \\
\hline \multicolumn{12}{|l|}{ Portugal } \\
\hline Credito Agricola & 1,710 & 1,685 & 1,659 & 1,786 & 1,611 & 1,778 & 2,080 & 2,242 & 2,501 & 2,580 & $+50.88 \%$ \\
\hline \multicolumn{12}{|l|}{ Slovenia } \\
\hline Dezelna Banka Slovenije d.d. & n.a. & 992 & 992 & 1,000 & 1,000 & 1,000 & 1,428 & 1,084 & 1,111 & 1,114 & $+12.30 \%^{a}$ \\
\hline \multicolumn{12}{|l|}{ Spain } \\
\hline Unión Nacional de Cooperativas de Crédito & n.a. & n.a. & 2,267 & 2,303 & 2,037 & 2,097 & 2,165 & 2,218 & 2,165 & 2,185 & $-3.62 \% b$ \\
\hline Banco de Crédito Cooperativo & n.a. & n.a. & n.a. & n.a. & 3,037 & 2,668 & 2,953 & 3,117 & 3,335 & 3,600 & $+18.54 \% d$ \\
\hline
\end{tabular}

Table A2: Consolidated and relationship-based cooperative banks in the euro area (2019).

\begin{tabular}{|c|c|c|c|c|c|}
\hline & Home country & Number of clients & $\begin{array}{l}\text { Number of legally indepen- } \\
\text { dent local or regional coop- } \\
\text { erative banks }\end{array}$ & $\begin{array}{l}\text { Number of branches (in } \\
\text { home country) }\end{array}$ & $\begin{array}{l}\text { Number of clients } \\
\text { per branch }\end{array}$ \\
\hline \multicolumn{6}{|l|}{ Panel A: Consolidated cooperative banks } \\
\hline Österreichischer Volksbanken & Austria & $1,072,639$ & 9 & 267 & 4,017 \\
\hline OP Financial Group & Finland & $3,894,000$ & 147 & 352 & 11,063 \\
\hline Crédit Agricole & France & $52,000,000$ & 39 & 8,400 & 6,190 \\
\hline Crédit Mutuel & France & $34,200,000$ & 18 & 5,000 & 6,840 \\
\hline BPCE & France & $30,000,000$ & 29 & $7,440^{a}$ & 4,032 \\
\hline Rabobank & Netherlands & $9,500,000$ & 89 & 371 & 25,606 \\
\hline Banco de Crédito Cooperativo & Spain & $3,441,666$ & 18 & 956 & 3,600 \\
\hline \multicolumn{6}{|l|}{ Panel B: Relationship-based cooperative banks } \\
\hline $\begin{array}{l}\text { Österreichische Raiffeisenbanken } \\
\text { Cooperative Financial Network - Bundesverband der Deutschen }\end{array}$ & Austria & $4,000,000$ & 368 & 1,781 & 2,246 \\
\hline $\begin{array}{l}\text { Volksbanken und Raiffeisenbanken (Volksbanks, Raiffeisenbanks, } \\
\text { Sparda-banks, PSD banks, and DZ banks) }\end{array}$ & Germany & $30,000,000$ & 841 & 9,344 & 3,211 \\
\hline $\begin{array}{l}\text { Cooperative Financial Network (Raiffeisen, Banco Popolare, and } \\
\text { Credito Cooperativo) }\end{array}$ & Italy & $6,000,000 b$ & 259 & 4,234 & 1,417 \\
\hline Banque Raiffeissen & Luxembourg & 122,547 & 1 & 38 & 3,225 \\
\hline $\begin{array}{l}\text { Credito Agricola } \\
\text { Col }\end{array}$ & 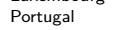 & $1,684,462$ & 79 & 653 & 2,580 \\
\hline Dezelna Banka Slovenije d.d. & Slovenia & 87,977 & 1 & 79 & 1,114 \\
\hline Unión Nacional de Cooperativas de Crédito & Spain & $7,064,825$ & 42 & 3,233 & 2,185 \\
\hline Median value & & $5,000,000$ & 41 & 1,369 & 3,413 \\
\hline
\end{tabular}

Notes: This table reports for the year 2019 the home country, the total numbers of clients, legally independent local or regional cooperative banks, branches (in home country) and clients per branch of consolidated and relationshipbased cooperative banks included in our sample. Prime source is EACB (2020b), which was elaborated in collaboration with Tilburg University and based on European Association of Co-operative Banks Members input (financial indicators on 31.12.2019).

$a_{\text {Data }}$ from 2018 .
Valculated by Tilburg University which bears the full and sole responsibility, as it is neither reported nor formally approved by the respective cooperative banks. 


\section{References}

Abbate, A. and Thaler, D. (2019). Monetary policy and the asset risk-taking channel. Journal of Money, Credit and Banking, 51(8):2115-2144.

Agarwal, S., Chomsisengphet, S., Liu, C., Song, C., and Souleles, N. (2018). Benefits of relationship banking: Evidence from consumer credit markets. Journal of Monetary Economics, 96:16-32.

Agarwal, S. and Hauswald, R. (2010). Distance and private information in lending. The Review of Financial Studies, 23(7):2757-2788.

Altavilla, C., Boucinha, M., and Peydro, J. (2018). Monetary policy and bank profitability in a low interest rate environment. Economic Policy, 33(96):531-586.

Altunbas, Y., Gambacorta, L., and Marques-lbanez, D. (2014). Does monetary policy affect bank risk? International Journal of Central Banking, 10(1):95-135.

Anderson, J. and Stallings, J. (2013). Restoring financing and growth to Europe's SMEs. Institute of International Finance.

Angeloni, I., Faia, E., and Duca, M. (2015). Monetary policy and risk taking. Journal of Economic Dynamics and Control, 52:285-307.

Athanasoglou, P. P., Brissimis, S. N., and Delis, M. D. (2008). Bank-specific, industry-specific and macroeconomic determinants of bank profitability. Journal of International Financial Markets, Institutions \& Money, 18(2):121-136.

Ayadi, R., De Groen, W., Sassi, I., Mathlouthi, W., Rey, H., and Aubry, O. (2016). Banking business models monitor 2015 Europe.

Ayadi, R., Llewellyn, D., Schmidt, R., Arbak, E., and De Groen, W. (2010). Investigating diversity in the banking sector in Europe: Key developments, performance and role of cooperative banks. Centre for European Policy Studies, Brussels.

Banerjee, R., Gambacorta, L., and Sette, E. (2017). The real effects of relationship lending. Bank of Italy - Temi di Discussione (Working Papers), (Number 1133 - September 2017).

Beck, T., Degryse, H., De Haas, R., and Van Horen, N. (2018). When arm's length is too far: Relationship banking over the credit cycle. Journal of Financial Economics, 127(1):176196.

Beltratti, A. and Stulz, R. (2012). The credit crisis around the globe: Why did some banks perform better? Journal of Financial Economics, 105(1):1-17.

Berger, A., Miller, N., Petersen, M., Rajan, R., and Stein, J. (2005). Does function follow organizational form? Evidence from the lending practices of large and small banks. Journal of Financial Economics, 76(2):237-269.

Berger, A. and Udell, G. (2002). Small business credit availability and relationship lending: The importance of bank organisational structure. The Economic Journal, 112(477):F32F53.
Bernini, C. and Brighi, P. (2018). Bank branches expansion, efficiency and local economic growth. Regional Studies, 52(10):1332-1345.

Bexley, J. (2016). How mergers are changing banking landscape. Academy of Strategic Management Journal, 15(2).

Bikker, J. and Vervliet, T. (2018). Bank profitability and risktaking under low interest rates. International Journal of Finance \& Economics, 23(1):3-18.

Bonfim, D. and Soares, C. (2018). The risk-taking channel of monetary policy: Exploring all avenues. Journal of Money, Credit and Banking, 50(7):1507-1541.

Boot, A. (2000). Relationship banking: What do we know? Journal of Financial Intermediation, 9(1):7-25.

Borio, C., Gambacorta, L., and Hofmann, B. (2017). The influence of monetary policy on bank profitability. International Finance, 20(1):48-63.

Borio, C. and Zhu, H. (2012). Capital regulation, risk-taking and monetary policy: A missing link in the transmission mechanism ? Journal of Financial Stability, 8(4):236-251.

Brana, S., Campmas, A., and Lapteacru, I. (2019). (Un)Conventional monetary policy and bank risk-taking: A nonlinear relationship. Economic Modelling, 81:576-593.

Buch, C., Eickmeier, S., and Prieto, E. (2014). In search for yield? Survey-based evidence on bank risk taking. Journal of Economic Dynamics and Control, 43:12-30.

Bülbül, D., Schmidt, R., and Schüwer, U. (2013). Savings banks and cooperative banks in Europe. SAFE White Paper Series (No. 5).

Busch, R. and Memmel, C. (2015). Banks' net interest margin and the level of interest rates. Deutsche Bundesbank, Research Centre Discussion Papers 16/2015.

Caselli, G., Figueira, C., and Nellis, J. (2020). Ownership diversity and the risk-taking channel of monetary policy transmission. Cambridge Journal of Economics.

Catturani, I. and Stefani, M. (2016). Italian credit cooperative banks. in: Credit cooperative institutions in European countries. Springer, Cham, pages 149-167.

Claessens, S., Coleman, N., and Donnelly, M. (2018). “Lowfor-long" interest rates and banks' interest margins and profitability: Cross-country evidence. Journal of Financial Intermediation, 35:1-16.

Cornée, S. (2014). Soft information and default prediction in cooperative and social banks. Journal of Entrepreneurial and Organizational Diversity, Special Issue on Cooperative Banks, 3(1):89-109.

Covas, F., Rezende, M., and Vojtech, C. (2015). Why are net interest margins of large banks so compressed? FEDS Notes, October.

Delis, M. D., Hasan, I., and Mylonidis, N. (2017). The risktaking channel of monetary policy in the US: Evidence from corporate loan data. Journal of Money, Credit and Banking, 49(1):187-213. 
Delis, M. D., Hasan, I., and Tsionas, E. G. (2014). The risk of financial intermediaries. Journal of Banking \& Finance, 44:1-12.

Delis, M. D. and Kouretas, G. P. (2011). Interest rates and bank risk-taking. Journal of Banking \& Finance, 35(4):840-855.

Dell'Ariccia, G., Laeven, L., and Marquez, R. (2014). Real interest rates, leverage and bank risk-taking. Journal of Economic Theory, 149:65-99.

Dell'Ariccia, G., Laeven, L., and Suarez, G. (2017). Bank leverage and monetary policy's risk-taking channel: Evidence from the United States. The Journal of Finance, 72(2):613-654.

Dell'Ariccia, G. and Marquez, R. (2006). Lending booms and lending standards. Journal of Finance, 61(5):2511-2546.

Demirgüç-Kunt, A. and Huizinga, H. (1999). Determinants of commercial bank interest margins and profitability: Some international evidence. The World Bank Economic Review, 13(2):379-408.

Dereeper, S., Lobez, F., and Statnik, J. (2020). Bank credit rates across the business cycle: Evidence from a French cooperative contracts database. Journal of Banking \& Finance, 112(105220).

Dinger, V. and te Kaat, D. (2020). Cross-border capital flows and bank risk-taking. Journal of Banking \& Finance, 117.

Distinguin, I., Roulet, C., and Tarazi, A. (2013). Bank regulatory capital and liquidity: Evidence from US and European publicly traded banks. Journal of Banking \& Finance, 37(9):3295-3317.

Donker, H., Ng, A., and Shao, P. (2020). Borrower distress and the efficiency of relationship banking. Journal of Banking \& Finance, 112(105275).

Drechsler, I., Savov, A., and Schnabl, P. (2017). The deposits channel of monetary policy. The Quarterly Journal of Economics, 132(4):1819-1876.

EACB (2020a). Annual report 2019. European Association of Co-operative Banks A.I.S.B.L.

EACB (2020b). Key figures for the year 2019. European Association of Co-operative Banks A.I.S.B.L.

Elekdag, S., Malik, S., and Mitra, S. (2020). Breaking the bank? A probabilistic assessment of euro area bank profitability. Journal of Banking \& Finance, 105949.

Elsas, R. (2005). Empirical determinants of relationship lending. Journal of Financial Intermediation, 14(1):32-57.

English, W., Van den Heuvel, S., and Zakrajsek, E. (2018). Interest rate risk and bank equity valuations. Journal of Monetary Economics, 98:80-97.

Ferrari, A., Masetti, O., and Ren, J. (2018). Interest rate caps: The theory and the practice. The World Bank - World Bank Policy Research Paper No. 8398.

Ferri, G., Kalmi, P., and Kerola, E. (2014). Does bank ownership affect lending behavior? Evidence from the Euro area. Journal of Banking \& Finance, 48:194-209.

Fiordelisi, F. and Mare, D. (2014). Competition and financial stability in European cooperative banks. Journal of International Money and Finance, 45:1-16.

Genay, H. (2014). What is the impact of a low interest rate environment on bank profitability? Chicago Fed Letter, 324(1).

Gomez, M., Landier, A., Sraer, D., and Thesmar, D. (2020). Banks' exposure to interest rate risk and the transmission of monetary policy. Journal of Monetary Economics.

Groeneveld, H. (2017). Snapshot of European co-operative banking 2017. Brussels: EACB, TIAS School for Business and Society.

Hansmann, H. (1996). The ownership of enterprise. Harvard University Press.

Hasan, I., Jackowicz, K., Kowalewski, O., and Kozlowski, L. (2014). Bank ownership, SME lending and local credit markets. Bank of Finland - Discussion Paper No. 22.

Hasan, I., Politsidis, P., and Sharma, Z. (2020). Bank lending during the COVID-19 pandemic. MPRA Paper no. 103565.

Houston, J., Lin, C., Lin, P., and Ma, Y. (2010). Creditor Rights, Information Sharing and Bank Risk Taking. Journal of Financial Economics, 96(3):485-512.

IJtsma, P., Spierdijk, L., and Shaffer, S. (2017). The concentration-stability controversy in banking: New evidence from the EU-25. Journal of Financial Stability, 33:273-284.

Jiménez, G., Ongena, S., Peydró, J. L., and Saurina, J. (2014). Hazardous times for monetary policy: What do twenty three million bank loans say about the effects of monetary policy on credit risk taking? Econometrica, 82(2):463-505.

Jiménez, G. and Saurina, J. (2004). Collateral, type of lender and relationship banking as determinants of credit risk. Journal of Banking \& Finance, 28(9):2191-2212.

Jovanovic, T., Arnold, C., and Voigt, K. (2017). Cooperative banks in need of transition: The influence of Basel III on the business model of German cooperative credit institutions. Journal of Co-operative Organization and Management, 5(1):39-47.

Khan, M. S., Scheule, H., and Wu, E. (2017). Funding liquidity and bank risk taking. Journal of Banking \& Finance, 82:203216.

Kuc, M. and Teply, P. (2019). Performance comparison of European cooperative and commercial banks in a low interest rate environment. Charles University Prague, Faculty of Social Sciences, Institute of Economic Studies - Paper No. 2019/36.

Laeven, L. and Levine, R. (2009). Bank governance, regulation and risk taking. Journal of Financial Economics, 93(2):259275.

Lang, F., Signore, S., and Gvetadze, S. (2016). The role of cooperative banks and smaller institutions for the financing of SMEs and small midcaps in Europe. EIF Working Paper 2016/36 - Research \& Market Analysis.

López-Espinosa, G., Mayordomo, S., and Moreno, A. (2017). When does relationship lending start to pay ? Journal of Financial Intermediation, 31:16-29. 
McKillop, D., French, D., Quinn, B., Sobiech, A., and Wilson, J. (2020). Cooperative financial institutions: A review of the literature. International Review of Financial Analysis, 101520.

Meyer, E. (2018). The new economic scenario and its impact on the cooperative banking business model. in: New cooperative banking in Europe - Palgrave Macmillan, Cham, pages 2945.

Neuberger, D., Pedergnana, M., and Rathke-Doppner, S. (2008). Concentration of banking relationships in Switzerland: The result of firm structure or banking market structure? Journal of Financial Services Research, 33(2):101-126.

Neuenkirch, M. and Nöckel, M. (2018). The risk-taking channel of monetary policy transmission in the euro area. Journal of Banking \& Finance, 93:71-91.

Ory, J. and Lemzeri, Y. (2012). Efficiency and hybridization in cooperative banking: The French case. Annals of Public and Cooperative Economics, 83(2):215-250.

Peltoniemi, J. (2007). The benefits of relationship banking: Evidence from small business financing in Finland. Journal of Financial Services Research, 31(2-3):153-171.

Petersen, M. and Rajan, R. (1994). The benefits of lending relationships: Evidence from small business data. The Journal of Finance, 49(1):3-37.

Presbitero, A. and Zazzaro, A. (2011). Competition and relationship lending: Friends or foes? Journal of Financial Intermediation, 20(3):387-413.

Rajan, R. (1992). Insiders and outsiders: The choice between informed and arm's-length debt. The Journal of Finance, 47(4):1367-1400.

Rajan, R. (2006). Has finance made the world riskier? European Financial Management, 12(4):499-533.

Ramayandi, A., Rawat, U., and Tang, H. (2014). Can low interest rates be harmful: An assessment of the bank risktaking channel in Asia. Asian Development Bank Working Paper Series on Regional Economic Integration.

Schmidt, J., Caccavaio, M., Carpinelli, L., and Marinelli, G. (2018). International spillovers of monetary policy: Evidence from France and Italy. Journal of International Money and Finance, 89:50-66.

Stein, J. (2012). Monetary policy as financial stability regulation. The Quarterly Journal of Economics, 127(1):57-95.

Uchida, H., Udell, G., and Yamori, N. (2012). Loan officers and relationship lending to SMEs. Journal of Financial Intermediation, 21(1):97-122.

Ullah, S., Akhtar, P., and Zaefarian, G. (2018). Dealing with endogeneity bias: The generalized method of moments (GMM) for panel data. Industrial Marketing Management, 71:69-78.

Valencia, F. (2014). Monetary policy, bank leverage and financial stability. Journal of Economic Dynamics and Control, 47:20-38.

Vari, M. (2020). Monetary policy transmission with interbank market fragmentation. Journal of Money, Credit and Banking, 52(2-3):409-440. 